IZA DP No. 9275

The Labour Market Effects of Academic and

Vocational Education over the Life Cycle: Evidence from Two British Cohorts

Giorgio Brunello

Lorenzo Rocco

August 2015 


\title{
The Labour Market Effects of Academic and Vocational Education over the Life Cycle: Evidence from Two British Cohorts
}

\author{
Giorgio Brunello \\ University of Padova, \\ CESifo, IZA and ROA \\ Lorenzo Rocco \\ University of Padova
}

\section{Discussion Paper No. 9275 \\ August 2015}

\author{
IZA \\ P.O. Box 7240 \\ 53072 Bonn \\ Germany \\ Phone: +49-228-3894-0 \\ Fax: +49-228-3894-180 \\ E-mail: iza@iza.org
}

Any opinions expressed here are those of the author(s) and not those of IZA. Research published in this series may include views on policy, but the institute itself takes no institutional policy positions. The IZA research network is committed to the IZA Guiding Principles of Research Integrity.

The Institute for the Study of Labor (IZA) in Bonn is a local and virtual international research center and a place of communication between science, politics and business. IZA is an independent nonprofit organization supported by Deutsche Post Foundation. The center is associated with the University of Bonn and offers a stimulating research environment through its international network, workshops and conferences, data service, project support, research visits and doctoral program. IZA engages in (i) original and internationally competitive research in all fields of labor economics, (ii) development of policy concepts, and (iii) dissemination of research results and concepts to the interested public.

IZA Discussion Papers often represent preliminary work and are circulated to encourage discussion. Citation of such a paper should account for its provisional character. A revised version may be available directly from the author. 


\title{
ABSTRACT \\ The Labour Market Effects of Academic and Vocational Education over the Life Cycle: Evidence from Two British Cohorts*
}

\begin{abstract}
Several commentators have argued that vocational education provides a smoother school to work transition than academic education. In the long - run, however, the skills it provides depreciate faster and individuals with this type of education are less capable of adapting to technical change. Because of this, its short - term advantages trade off with expected longterm disadvantages in terms of employment, wages or both. Using two UK cohort studies, that allow us to follow individuals for at least 16 years in the labour market, we investigate whether this view has empirical support. For employment, our results indicate that the initial advantage associated to vocational education declines over time, without turning however into a disadvantage at later ages. For real net wages, the picture is more nuanced, with results that vary by cohort and educational level. Overall, our evidence suggests that vocational education is associated to lower expected long-term utility only for the younger cohort with higher (post-secondary) education. We further distinguish between dominant and non-dominant vocational education to account for the different bundles of skills held by individuals, and find that those with a more balanced bundle tend to have higher expected long-term earnings.
\end{abstract}

JEL Classification: J31

Keywords: vocational, academic education, UK

Corresponding author:

Giorgio Brunello

Department of Economics

University of Padova

Via del Santo 33

35100 Padova

Italy

E-mail: giorgio.brunello@unipd.it

\footnotetext{
* We are grateful to Marco Bertoni, Peter Dolton and the audience at a seminar in Sussex for comments and to Maria Navarro Paniagua for help with the UK data.
} 


\section{Introduction}

Education economists often point out that individuals with a vocational education face a trade-off between short term benefits and long term costs. In the short term, this type of education facilitates the transition from school to the labour market by providing ready to use skills. In the long term, however, vocational skills depreciate relatively fast and individuals who specialize in this skills are less capable of adapting to technical change than individuals endowed with a more academically oriented education.

Because of this alleged trade-off, the initial advantage provided by vocational education decreases with age and can even turn into a disadvantage, not only for the individual but also for the aggregate economy: the relative diffusion of vocational education is seen as one of the reasons for Europe lags behind the U.S. in its ability to adopt new technologies (see Krueger and Kumar, 2004).

In this view, the labour market benefits of vocational education are short lived. Empirical support for this has been recently provided by Hanushek, Wossmann and Zhang, 2011, using data from the International Adult Literacy Survey (IALS). These authors adopt a "difference - in - differences" approach and compare the life cycle patterns of employment for individuals with vocational and academic education. Since IALS does not allow to distinguish between age and cohort effects, they need to assume that age - employment and age - wage profiles do not vary across cohorts, so that today's old people in each education category are a good proxy for today's young people when they will become old.

In this paper, we address the same question as Hanushek and al, 2011, - whether the alleged benefits of vocational education at labour market entry disappear with age and even turn into disadvantages with age and labour market experience - without relying for identification on the assumption that employment and wage profiles are invariant across cohorts. Given that the contents of vocational and academic education have changed over time and across cohorts in several developed countries, we believe that such assumption is unlikely to hold. On the one hand, vocational curricula have been broadened to reflect the demand for more flexible job roles (see Green, 2002); on the other hand, the academic content of vocational programmes have been enhanced, both to maintain the attractiveness of these programmes in times of academic drift and to facilitate the development of links connecting different curricula (see Green, Wolf and Laney, 1999, Cedefop, 2008).

In contrast to Hanushek and co-authors, our empirical strategy exploits only within-cohort variations in labour market outcomes. For this purpose, we use two long cohort studies of Britons, whom we follow for an extensive period of time, from age 23 to age 55 in the case of the 
older cohort born in 1958, and from age 26 to age 42 for the younger cohort born in 1970. By construction, these data allow us to distinguish between age and cohort effects and to obtain cohort-specific estimates of age - employment and age - wage profiles.

Although the UK is not usually considered to be a country where vocational education plays a prominent role, as in some Central European countries, the Wolf Report, 2011, shows that this type of education is by no means marginal in this country. In the UK..."...14-19 education covers 'academic' as well as 'vocational' subjects. A small minority follow entirely academic GCSEs, but most 14-16 year olds take some form of 'vocational' qualification, and some follow a programme in which GCSEs play quite a small part. Post-GCSE, about a third take only A levels, the conventional 'academic' route. In other words, two-thirds do not - and almost all of these young people will spend all or some of the years from 16 to 19 on courses which are partly or wholly 'vocational'... (Wolf, p.20). Compared to vocational education in Germany, characterised by the famed dual system alternating school to work, vocational education in the UK is mostly school based.

Cohort studies have advantages, such as large sample sizes and the presence of detailed information on individual education and early life conditions, which can be used to distinguish both between vocational and academic education and between education levels. This advantage trades off with the limited generalizability of results. Our empirical findings apply to a single country and two specific cohorts, who acquired their secondary and tertiary education in the 1970s and 1980s. Whether they hold also for more recent cohorts is an open question that we cannot address with the data at hand. However, since our empirical findings show important differences across cohorts that are only 12 years apart, we suspect that the answer to this question is negative.

The allocation of individuals to education types, and in particular to academic and vocational education, is not free of ambiguities. First, many have acquired both academic and vocational qualification during their education. Second, qualifications that are usually classified as academic may have an important vocational content (see Makepeace and Dolton, 2001, for a discussion). ${ }^{1}$ We allocate individuals to vocational or academic education using their highest qualification acquired by their early twenties, when most young Britons have completed their full time education. Our strategy is not new in this literature (see Dearden et al, 2002, for a discussion), and assumes that attained qualifications below the highest affect labour market outcomes only insofar as they influence the probability of attaining the highest degree. For both vocational and academic education, we distinguish between two levels, "lower" and "higher", depending on

\footnotetext{
${ }^{1}$ We only consider vocational formal education and exclude purely informal, work-based learning, adult training and
} lifelong learning, or participation in labour market programmes. 
whether the highest attained qualification belongs to National Vocational Qualification level 2/3 - roughly corresponding to the more popular ISCED 3 - or 4/5, corresponding to ISCED 5 (see Schneider, 2008), and conduct our comparisons within each level.

By focusing on the highest education qualification, we ignore that individuals with the same highest qualification may differ in the bundle of other attained qualifications. This is particularly important in the case of vocational education, for which we find many instances of individuals having a fairly close academic qualification as well. We therefore propose an additional distinction, between "dominant" and "non - dominant" vocational education, with the former obtaining when the distance in NVQ levels between the highest vocational qualification and the highest academic qualification is at least equal to two and the latter when the distance is lower. ${ }^{2}$

Any evaluation of the economic costs and benefits of education types that tries to identify causal effects faces the threat of selection bias. ${ }^{3}$ To address this threat, we estimate separately the effects of time invariant education type on employment and wages at the initial available age (23 for NCDS and 26 for BCS) and changes in these effects as individuals spend time in the labour market. To estimate changes, we use a fixed-effects estimator, which delivers consistent estimates of the interactions between age and education type. To estimate the effects at the initial available age, we use the AIPW (augmented inverse probability weighted) estimator, which relies on selection on observables. Following Blundell et al, 2000, we argue that the rich set of measures of individual ability and early life conditions available in our data makes this assumption particularly tenable.

We combine the fixed effects and AIPW estimates to simulate average employment and earnings profiles by age and compute expected lifetime earnings for each education type, or the discounted sum of expected earnings from the initial to the final available age in our data. This concept corresponds to expected utility if individuals are risk neutral. As a measure of earnings risk, we also compute for each education type and at each age the coefficient of variation of earnings.

Our empirical estimates indicate that the life cycle pattern of employment probabilities by education type is rather similar across the two cohorts. A statistically significant early employment advantage for vocational education exists, albeit only at the higher education level, and lasts until individuals are in their early thirties. At later ages, employment profiles by education type do not significantly diverge. Rather, the profiles associated to vocational education are statistically indistinguishable from those associated to academic education at the lower education level and lie

\footnotetext{
2 In either case the highest qualification is vocational.

3 “...In the presence of correlations between unobserved personal attributes, on the one hand, and educational pathway and labour market outcomes on the other, the statistical association between pathway and outcome 'picks up' the effect of the unobserved attributes as well..." (Ryan, 2003, p.153)
} 
above the latter at the higher education level. While these results are broadly consistent with the view that the early advantages of vocational education decrease with age, they do not generally support the existence of a trade-off between early employment advantages and later disadvantages.

Cross cohort differences are sharper when we consider real net wages. For the older cohort, we find that those with vocational education enjoy an early advantage over those with academic education, which rapidly disappears with age and even turn into a disadvantage for those with lower education. For the younger cohort, there is no evidence of an early advantage, and those with higher vocational education suffer a persistent disadvantage with respect to the comparison group with academic education. Therefore, our evidence indicates that having a vocational education can lead to short-term real wage advantages, and that these advantages could translate over time and age into long-term disadvantages with respect to having an academic education.

When we combine the information provided by employment and wage profiles by computing expected long-term earnings, we find that vocational education is associated to lower earnings only for two of the four groups under study: the lower educated in the older cohort and the higher educated in the younger cohort (see Table 1). If we also consider the estimated coefficient of variation of earnings, however, we conclude that vocational education is likely to yield lower expected long-term utility than academic education only for the younger cohort with higher education.

The differences in employment and wage profiles across cohorts that we document in this paper call into question the validity of assuming that the old today are a good proxy of the today's young in thirty years, which require that profiles vary by age but not by cohort. While some of our findings are in line with the results by Hanushek et al, 2011, there are also several differences.

They find that individuals completing academic education are more likely by age 50 to be employed than individuals completing vocational education. In contrast, we find that employment at age 50 is about as high or even higher for those with vocational education. Hanushek et al pool together individuals with upper secondary and tertiary education. Our data suggest instead that - at least for the UK and the two cohorts under study - the life cycle patterns of academic and vocational education differ importantly across education levels.

Our paper is organised as follows. Section 1 provides a review of the relevant economic literature. We introduce the data in Section 2 and our empirical approach in Section 3. Results are discussed in Sections 4 and 5. Conclusions follow. 


\section{Literature review}

A merit of vocational education often recognized in the economic literature is that it improves the labour market opportunities of youths who lack the resources, skills or motivation to continue with higher education. Many have argued that this type of education provides useful skills to prepare these individuals for labour market entry and improve their chances of a successful professional career. In an influential paper, Ryan, 2001, summarises the cross-country evidence by showing that vocational programmes, and particularly apprenticeships, increase the chances of an early working life. Quintini and Manfredi, 2009, study the patterns of school - to work transitions in Europe and the US and confirm that the most successful European countries in terms of school-to-work transitions are those where apprenticeships are widespread.

More recently, CEDEFOP, 2013, has investigated the relationship between vocational education and school - to - work transition using the individual anonymised micro data from the core and ad hoc modules of the 2009 European Union Labour Force Survey (EU-LFS), which provides detailed information on the transition of young individuals from education to work. The results indicate that vocational education is capable of speeding up this transition. Relative to graduates with medium-level academic education, graduates with vocational education enjoy a faster transition to work, are more likely to have a permanent first job, and are less likely to find a first job with a qualification mismatch. ${ }^{4}$

It is often argued that the recognized advantage of vocational education in the provision of ready to use skills, and therefore its ability to facilitate the transition from school to work (e.g. Wolter and Ryan, 2011), comes at the price of skills becoming quickly obsolete in modern economies characterized by rapid technological change (e.g. Krueger and Kumar, 2004). Yet the empirical evidence that a trade-off between initial advantages and later disadvantages characterizes the labour market performance of vocational education is still rather scant.

In one of the few studies that investigate this trade-off, Hanushek et al, 2011, use cross country and cross cohort data to study the employment patterns of several cohorts of graduates with academic and vocational education and find that younger individuals with academic education face worse employment conditions than similarly aged individuals who specialize in vocational skills. Conversely, older individuals with academic education have better employment prospects, suggesting that occupation-specific knowledge depreciates faster and hence leads to lower employment opportunities later in life.

In another study focusing on Sweden, Goldsteyn and Sterberg, 2015, use register data of earnings from 1978 to 2011 to compare life cycle earnings of individuals with vocational and

\footnotetext{
${ }^{4}$ Similar results are reported by Brunello and Rocco, 2015, using PIAAC data. See also Verhaest and Baert, 2015.
} 
general education. They find that for males vocational education is associated to an initial relative earnings advantage, that turns into a disadvantage after about 10 years in the labour market. For females, the switch into disadvantage occurs much earlier.

While research on the labour market performance of vocational education over the life cycle is still rather limited, substantial research in the past few decades has explored how education types affect labour market outcomes, including earnings and current employment status. This research has produced estimates of the economic returns to different curricula, focusing in particular on the comparison between academic and vocational education. Data limitations, however, have restricted cross-country comparative analysis.

U.S. based research includes Hotchkiss, 1993, who studies the effects of vocational schooling on employment and wages for high-school graduates in 1980, and finds no returns to vocational schooling even after controlling for training-related occupation choice. In contrast, Bishop and Mañe, 2004, find that students who take a certain percentage of vocational subjects in secondary school are more likely to earn higher wages and display higher participation rates than students with a more academic education. Meer, 2007, also finds positive wage effects associated to vocational education, but smaller than in Bishop and Mane.

In the UK, earlier studies comparing the returns to vocational and academic schooling have frequently found markedly lower returns to vocational education (see for instance Robinson 1997). Dearden, McIntosh, Myck and Vignoles, 2002, confirm the finding that academic education leads to higher returns, but also document that the majority of vocational education programs increase earnings relative to no vocational qualifications, especially for low achieving school leavers. More recently, Bibby et al, 2014, compare returns to different curricula using matched administrative data and find that returns to workplace level vocational education are higher than those from classroom level vocational studies.

Empirical research on the economic effects of education types faces the difficult task of controlling in a credible way the endogenous selection into different curricula. ${ }^{5}$ The few studies that have been able to use exogenous policy changes to control for self-selection find no statistically significant differences in the labour market outcomes associated to education types. Oosterbeek and Webbink, 2007, evaluate the effect on earnings of extending three-years basic vocational programs with one year of academic education - a policy that took place in the Netherlands in 1975. Adopting a difference-in-differences strategy, they find no effect on wages twenty years later.

Pischke and von Wachter, 2008, use the gradual adoption of a one - year increase in compulsory schooling in the lowest schooling track in Germany between the 1950s and the 1970s

5 See Ryan, 2003, and Altonji, Bloom and Meghir, 2012 for discussions. 
to investigate changes in long-term wages, but also fail to find an effect. Hall, 2012, evaluates a policy change in Sweden in 1991 that increased the academic content of upper secondary vocational education. Using the differences in the regional implementation of a policy pilot, she finds no effects of the policy on wages earned up to 16 years after the beginning of secondary school.

Using a natural experiment, Malamud and Pop-Eleches, 2010, find that vocational education graduates in Romania are significantly more likely to work as manual workers and craft-men than are graduates with academic education. However, there is no significant difference between vocational and academic education in terms participation rates, unemployment rates, periods of non-employment, and family income. Finally, Fersterer et al., 2008, find that Austrian apprentices earn no significant wage premium when compared to other forms of school - based education, such as those taking place in colleges or vocational schools.

In the UK, studies investigating how labour market outcomes change between vocational and academic education have often turned to the National Child Development Study (NCDS) as a valuable source of data. Blundell et al, 2000, for instance, use NCDS to examine the impact that degree-level qualifications and other higher education qualifications have on wages at age 33 in 1991. Using selection on observables, they compare average returns with and without controlling for individual ability and estimate that, when ability is not controlled, returns to an undergraduate degree are around 21\% for men and 39\% for women. Controlling for ability at age seven, region, school type, family background, demographic characteristics and various other features of the job (for example, employer size and unionisation) these returns decline to around $17 \%$ for men and $37 \%$ for women.

In a more recent paper, Blundell et al, 2005, emphasize the importance of correcting for detailed test score and family background differences and of allowing for (observable) heterogeneity in returns. They find an average return of $27 \%$ for those completing higher education versus anything less. Compared with ending school at age 16 without qualifications, they also find an average return to O-levels of $18 \%$, to A-levels of $24 \%$ and to higher education of $48 \%$.

Using data from the 1991 sweep of the National Child Development Study (NCDS) and the 1998 Labour Force Survey (LFS), Dearden and al, 2002, investigate the labour market returns to academic and vocational qualifications. They find that the wage premia associated to academic qualifications are typically higher than those accruing to vocational qualifications. However, this gap is somewhat reduced when they control for the time required to acquire different 
qualifications. This is particularly important for vocational courses, which generally take shorter time to complete. ${ }^{6}$

\section{Data}

Our data are drawn from two sources, the National Child Development Study (NCDS) and the British Cohort Survey (BCS). Both cohort studies are continuing longitudinal surveys of people living in Great Britain who were born in March 1958 and April 1970 respectively. The NCDS has survey information available at ages 7, 11, 16, 23, 33, 42, 46, 50 and 55. The BCS is very similar, with information available at ages 5, 10, 16, 26, 30, 34, 38 and 42 (see Makepeace and Dolton, 2001, and Blanden and Machin, 2004 for further details).

The NCDS covers a much longer period of adult life than the BCS, and therefore provides a more complete picture of the life cycle pattern of employment and wages. In this study, we focus mainly on this survey, but use also BCS data to verify whether and to what extent our findings vary by cohort. As in Dearden, 1999, we consider only men, who have a more stable labour market attachment than women, and study their employment and wage profiles from age 23 to 55. Age 23 is the first occasion when cohort members reply directly to the NCDS survey. By that age, more than 90 percent have already left full time education.

\subsection{Educational qualifications}

We take the 1981 wave of NCDS as the starting point of our longitudinal analysis, using variables from previous sweeps to measure both individual cognitive abilities at age 7 and 11 and early life conditions, and define the educational attainment of each individual in our sample as the highest qualification attained by age 23. Individuals older than 16 in the UK can take a broad range of qualifications, both academic and vocational. Following Dearden et al, 2000, these qualifications can be classified into five different levels - with 1 the lowest and 5 the highest using the National Vocational Qualification system (NVQ) as reference.

Roughly, NVQ level 1 corresponds to approximately ten years of schooling, NVQ levels 2 and 3 to eleven to twelve years and NVQ levels 4 and 5 to fourteen to fifteen years. ${ }^{7}$ Furthermore, NVQ 2 and 3 roughly correspond to the more commonly used ISCED level 3, while NVQ 4 and 5 correspond to ISCED 5 (see Schneider, 2008). Following Dearden et al, 2002, and Dodgeon et al, 2011, for each individual in the sample we first obtain his highest

\footnotetext{
${ }^{6}$ Dolton and Vignoles, 2002, use these data to investigate the returns to a broader curriculum.

${ }^{7}$ See Dearden et al, 2004, for a detailed description of the contents of NVQ levels.
} 
academic and vocational qualification - in NVQ levels - and then define his highest qualification (academic or vocational) as the one with the highest NVQ level. ${ }^{8}$

We use this information to allocate individuals to one of the following five education groups: low education (LE), corresponding to no education or to the National Vocational Qualification (NQV) level 1; lower vocational (V1) and academic (G1) education, corresponding to NQV levels $2 / 3$, and higher vocational (V2) and academic education (G2) for NQV levels 4/5. Since lower and higher education levels are associated to a different average number of years of schooling, in this study we choose to compare the labour market outcomes of vocational and academic education within levels (V1 with G1 and V2 with G2 respectively) rather than across levels.

We proceed in a similar way for the BCS cohort. In this case, we use the information on attained qualifications and attainment year provided by the 2000 wave to compute for each individual his highest qualification - vocational or academic - at age $23 .{ }^{9}$ Further details on our classification strategy are relegated to the Appendix. The first column in Table 2 shows the distribution of individuals by their highest attained qualification at age 23 in our NCDS 1981 sample. Low education covers close to 36 percent of respondents. Males whose highest education is lower vocational or academic, corresponding to NVQ 2 and 3, are 32.2 and 13.9 percent, and males with higher vocational and academic education (NVQ 4 and 5) as their highest attainment are 5.0 and 12.9 percent respectively.

Column (2) reports the same distribution for individuals born in 1970, using BCS data. We find that the younger cohort has higher average education, due both to the significant reduction in the percentage of those with low education (27.1 compared to 36 percent) and to the sharp increase in the share of those with higher education - or NVQ 4/5 (27.0 compared to 17.9 percent). There is also a change between cohorts in the composition of NVQ 2/3 education, with a shift from vocational to academic qualifications.

The significant increase in the percentage of individuals with higher education between the two cohorts is consistent with the substantial expansion of higher education - documented by Devereux and Fen, 2011, and Walker and Zhu, 2008, among others - which affected mainly the cohorts born between 1970 and 1975. Blanden and Machin, 2004, show that this expansion influenced also the proportion of people who stayed in education beyond age 16. In the last row

\footnotetext{
${ }^{8}$ In the event of ties (highest vocational and academic qualification belongs to the same NVQ level) we assign the highest qualification to vocational or academic using the information on the latest qualification.

${ }_{9}$ We do not use the educational information in the 1996 wave because in that wave - due to the absence of an interviewer - a significant number of respondents put down a level of highest qualification above that stated four year later. See Dodgeon et al, 2011, for details. However, we use this wave for information on employment and earnings at age 26.
} 
of Table 2 we show that this proportion fell from 70.2 percent for the cohort born in 1958 to 61.4 percent for the younger cohort.

By focusing on the highest qualification we implicitly assume that lower qualifications affect labour market outcomes only insofar as they influence the probability of attaining the highest degree. We also ignore that individuals with the same highest qualification may differ in the bundle of qualifications held, part of them vocational and part academic. To illustrate, consider two individuals, who share the fact of having highest vocational qualification at level NVQ 4, but differ because the former individual also holds a NVQ 3 highest academic qualification, while the latter only has a level NVQ 2 highest academic degree. While the former individual has a more balanced set of vocational and academic qualifications, the latter individual specializes more in vocational degrees. Conditional on the same highest educational level, the two individuals may have different labour market outcomes because of their different degree of specialization in vocational studies.

To capture this potential source of heterogeneity, we classify individuals as having a "dominant" vocational (academic) education when the gap between highest vocational (academic) and academic (vocational) NVQ qualifications is at least equal to 2, and as having a "non-dominant" vocational (academic) education when the gap is at most equal to 1 NVQ level. In the previous example, the former individual would belong to the first group, and the latter individual to the second group. Table 3 shows the percent of individuals in our sample with dominant vocational or academic highest qualifications. We notice two things: first, this percentage is always higher when the highest qualification is academic, reaching close to 100 percent in NCDS for the G2 group; second, the percentage with dominant highest qualifications is always higher in the older cohort. Given that the percentage of individuals with a non dominant pattern of qualifications is relatively low both for the higher education group and for those with lower academic education, we shall only distinguish hereafter between dominant and non dominant lower vocational education.

We focus on educational attainment in the early twenties, but of course the acquisition of additional qualifications is an ongoing process that continues over time. Although only 2.4 percent of the individuals in the NCDS 1981 sample are in full education, between 17.7 and 28.0 percent of those interviewed between 1991 and 2013 have gained additional qualifications since the previous interview, with the percentage increasing with the level of education in 1981 . The percentage involved in workplace training since the previous interview is also relatively high, ranging from 24.9 percent for those with low education to 41.2 percent for those with higher vocational education. 
We use seven waves of NCDS, spanning a period from 1981 to 2013, and five waves of BCS, ranging from 1996 to 2012, and focus on two key labour market outcomes, the probability of employment and real annual net earnings. Table 4 shows the sample means of these outcomes by education type and cohort. In NCDS, the average probability of being employed over the life cycle ranges between about 83 percent for those with low education to 93.5 percent for those with higher vocational education as their highest degree. Real average annual net earnings (2005 prices) range from about 14.4 thousand pounds for those with low education to 23.8 thousand pounds for those with higher academic education as their highest degree. In BCS, average employment probabilities range from 82.6 percent among the low educated to 95.6 percent among those with higher vocational education, and average real annual net earnings range from 16.2 in the former group to 26.4 thousand pounds in the latter group.

Table 5 shows the means and standard deviations of the probability of employment and real net wages for those with dominant and non-dominant lower vocational education. Both outcomes are higher for the latter group. We use the math test score at age 7 as an indicator of cognitive ability in early age. As expected, measured ability is highest for those who have attained academic education as their highest degree and lowest for those with low education - see the final row in the first panel of Table 4. Finally, Table A2 shows the mean value of measured early life conditions in NCDS data, which include: weight at birth in ounces, left-handiness, whether breastfed, whether mother smoked during pregnancy, showed interest in the child's education, was not in school at 16, read to child and had no abnormal pregnancy, whether the father was in a low ranking occupation or not at school at 16 and finally whether household had difficult times.

\subsection{Attrition}

Because of attrition, our NCDS sample of 6,169 males in 1981 is reduced to 3,599 individuals in 2013. Blundell et al, 2000, investigate whether the attrition occurring until wave 5 (1991) can bias the composition of their main sample and find that it is similar to that of the Labour Force Survey, a large-scale endeavour that is not affected by panel attrition. Lindeboom et al, 2009, quote evidence from The National Child Development Survey Use Support Group, showing that sample survivors do not differ from the original sample to any relevant extent in terms of social and economic status, education and health.

Attrition is relevant for us if it varies significantly across education types, thereby affecting life cycle profiles by type. We investigate whether this is the case by using data on men who were 
present in the 1981 wave but did not respond in waves 5 to 9 (1991 to 2013). We regress the probability of non-response in the past two, three, four and five waves on indicators of early life conditions, ability at ages 7 and 11 as measured by test scores, and four dummies, one for each education type above low education: lower vocational education, lower academic education , higher vocation education and higher academic education. ${ }^{10}$ Our results, based on a probit specification, are shown in Table 6. Clearly, non-response is highest among those with low education (NVQ level 1 or below). However, when we test whether it varies by education type (vocational or academic above NVQ level 1), we find that in all specifications we cannot reject the null of no significant difference. We interpret this as evidence that selective attrition in NCDS is not a problem when comparing the labour market outcomes of vocational and academic education.

\section{The empirical setup}

Following Hanushek et al, 2011, we investigate the life cycle effects of different education types by estimating the following multi-treatment empirical model

$$
\mathrm{Y}_{\mathrm{it}}=\beta_{0}+\sum_{\mathrm{s}}^{4} \beta_{\mathrm{s}} \mathrm{T}_{\mathrm{is}}+\sum_{\mathrm{j}=1}^{5} \gamma_{\mathrm{j}} \mathrm{A}_{\mathrm{ij}}+\delta \mathrm{X}_{\mathrm{i}}+\sum_{\mathrm{s}=1}^{4} \sum_{\mathrm{j}=1}^{5} \pi_{\mathrm{js}} \mathrm{T}_{\mathrm{s}} \mathrm{A}_{\mathrm{j}}+\phi A G \mathrm{E}_{\mathrm{it}} \mathrm{X}_{\mathrm{i}}+\rho \mathrm{U}_{\mathrm{rt}}+\mathrm{u}_{\mathrm{i}}+\varepsilon_{\mathrm{it}}
$$

where $\mathrm{Y}$ is the individual outcome, $\mathrm{T}$ is a set of dummies capturing education type at age 23 , one each for lower (NVQ levels 2-3) and higher (NVQ levels 4-5) vocational education (V1 and V2), and for lower and higher academic education (G1 and G2); ${ }^{11} \mathrm{~A}$ is a vector of age dummies for ages 33 to 55 for NCDS (age 23 is in the constant term) and for ages 30 to 42 for BCS (age 26 in the constant term); $\mathrm{X}$ is a vector of demeaned predetermined controls that includes early life conditions as well as measures of individual ability; ${ }^{12} \mathrm{U}$ is the regional unemployment rate at time $\mathrm{t}, \mathrm{AGE}$ is an age trend, $u$ is the individual fixed effect and $\varepsilon$ is a random error.

The individual fixed effect captures the unobserved time invariant traits that influence the selection of education type by age 23 as well as labour market participation and the probability of having non-negative earnings. Since this probability may also be affected by temporary shocks to

\footnotetext{
${ }^{10}$ Lower education (at most National Vocational Qualification level 1) is in the constant term.

${ }^{11}$ Lower education is in the constant term.

12 Measures of cognitive ability include math and reading test scores at age 7 and 11. Indicators of early life conditions that are likely to affect the early stage development of ability are height at 7 , weight at birth, the father's occupation, whether the father or the mother stayed at school after age 16, left handiness, whether breastfed, whether the mother read to child or showed interest in the child's education, and whether she smoked during pregnancy.
} 
the economy, we control for the regional time varying unemployment rate (see Blundell, Dearden and Meghir, 1996, for a similar approach). We are interested in estimating how the life cycle profile of outcome Y varies with the four education types V1, G1, V2 and G2 (our treatments). For this purpose, we include in (1) the interactions of five age dummies (age 33, 42, 46, 50 and 55) for NCDS and four age dummies (age 30, 34, 38 and 42) for BCS with the four education types.

Observed differences in the life cycle patterns of labour market outcomes such as wages and employment can reflect both education types and differences in ability. For instance, more talented individuals may enjoy higher earnings and employment growth than less talented workers, independently of whether their education is vocational or academic. When ability conditional on education matters, failure to control for the interactions of age and ability in regression (1) may lead to erroneously conclude that the observed life cycle differences in labour market outcomes are driven by education types. We account for the possibility that the effect of predetermined characteristics $X$, that include measured ability, varies by age by using a relatively parsimonious specification, which adds to the regression the interactions of the variables in vector $X$ with an age trend rather than with age dummies.

Since education type is correlated with individual unobservables, self-selection into types implies that the parameters $\beta_{0}$ and $\beta_{\mathrm{s}}, \mathrm{s}=1, . ., 4$, do not identify the impact of each education type on $\mathrm{Y}$ at the initial age ( 23 for NCDS and 26 for BCS). One solution to this problem is a conditional independence assumption: conditional on the vector of controls $X$, the assignment to treatment (education type) can be considered as random. This strategy has been followed in the previous literature, both by Blundell et al, 2000, and by Dearden et al, 2002, for two main reasons: first, these authors were interested in estimating the returns to education type at one particular age; second, the NCDS provides an unusually rich set of controls for early ability and early life conditions, which make selection on observable a relatively attractive option.

Our approach is partially different. We estimate separately the parameters that measure the effects of each education type on labour market outcomes at the initial available age, $\beta_{0}+\beta_{\mathrm{s}}$, and the parameters $\pi_{\mathrm{js}}$, that capture the changes in these effects as individuals age. As in Blundell et al, 2000, and Dearden et all, 2002, we estimate the former group of parameters under a conditional independence assumption, exploiting the rich set of observables available in NCDS and BCS data, which include measures of cognitive ability at age 7 and 11 and indicators of early life conditions, and using the AIPW estimator, developed to estimate treatment effects in nonrandom trials. Non-random assignment to treatment implies that some individual characteristics could be over-represented either in the treatment or the control group and need re-balancing 
before computing treatment effects. With the AIPW estimator, re-balancing is obtained by jointly estimating a treatment model and an outcome model. This procedure has the desirable property of being double robust to misspecification. ${ }^{13}$ We describe how we apply this method to our data in the Appendix.

We estimate the latter group of parameters with a fixed effects estimator, that exploits the within-individual variation in the data and is robust to self-selection into education due to unobservable time invariant traits. To satisfy the common support requirement, essential to avoid extrapolations in the estimation of $\beta_{0}+\beta_{\mathrm{s}}$ and of $\pi_{\mathrm{js}}$, we retain in our final sample of individuals only those with an estimated propensity score equal to at least 1 percent for each possible treatment. ${ }^{14}$ We combine our estimates of $\beta_{0}+\beta_{\mathrm{s}}$ and $\pi_{\mathrm{js}}$ to compute average age employment and age - wage profiles. For each age, we estimate the relevant standard errors by bootstrapping the entire procedure 250 times.

Since individuals typically care about both employment and wages, we compute average longterm earnings LW

$$
\mathrm{LW}_{\mathrm{S}}=\sum_{\mathrm{t}=23}^{55} \frac{\mathrm{E}_{\mathrm{st}} \mathrm{W}_{\mathrm{st}}}{(1+\mathrm{r})^{\mathrm{t}-23}}
$$

where $\mathrm{E}$ is the probability of employment at time $t$ for treatment $s, w$ is the real net wage and $r$ is the real rate of interest, that we set at 2 percent (see Brunello, Weber and Weiss, 2015). This concept implicitly assumes that earnings from unemployment are equal to zero, which is not crucial for us if unemployment benefits do not vary much by education type, and corresponds to expected long-term utility if individuals are risk neutral.

Earnings profiles by education type that share the same value of LW may differ in the variability of employment and earnings over the life cycle. If individuals are risk averse, their individual utility is increasing in LW and decreasing in the variance of expected earnings. For each education type and available wave, an important component of this variance is the coefficient of variation of earnings $\mathrm{CV}_{\mathrm{s}}$, that we compute after re-balancing on observables using the sample that satisfies the condition of common support. ${ }^{15}$ We regress $\mathrm{CV}_{\mathrm{S}}$ on a quadratic in

\footnotetext{
13 The property says that only one between the treatment and the outcome model needs to be correctly specified for the estimate of potential outcomes to be unbiased.

14 We select the common support using the 1981 wave for NCDS and the 2000 wave for BCS.

15 The coefficient of variation of employment when the underlying distribution is binomial is $\sqrt{\frac{1-\mathrm{p}}{\mathrm{p}}}$, where $p$ is
} mean employment. 
age and the four treatment dummies and use the estimated parameters of these dummies to evaluate whether, conditional on age, $\mathrm{CV}_{\mathrm{s}}$ varies significantly by treatment.

A clear advantage of NCDS and BCS data is that they are long panels of individuals belonging to the same birth cohort, covering from 16 to more than 30 years of productive life. By construction, cohort and age effects in these data are clearly distinguishable, although age and time effects are not. In our empirical specifications, we partly control for the effects of macro shocks (time effects) by including in (1) the regional unemployment rate. However, since our purpose is to study the labour market performance over the life cycle of individuals with different education types, the distinction between age and time effects is not of crucial importance. As time goes by, individuals with different skills and education type are exposed both to ageing and to a sequence of macro shocks, which test their ability to adapt and impact on the effectiveness of accumulated skills. Hence, we do not try to distinguish between age and time effects in our empirical study and, in the presentation of results, we shall use the word "age" as synonimous of "time".

\section{Results using NCDS}

\subsection{Baseline results}

We estimate (1) by fixed effects, using as dependent variables: the employment dummy $E$, equal to 1 if the individual is employed and to 0 otherwise; real net earnings $w$; the dummy $Q$, equal to 1 if additional qualifications have been attained between the current and the previous wave and to 0 otherwise; the dummy $T$, equal to 1 if any work related training has been done between the current and the previous wave, ando to 0 otherwise. ${ }^{16}$ Table A3 in the Appendix presents the results. For the three dependent variables that are dummies, we use linear probability models. ${ }^{17}$

We use these estimates to compute for each age and education level - low or high - the gap $\pi_{\mathrm{jV}}-\pi_{\mathrm{jG}}$, with $\mathrm{V}$ for vocational and $\mathrm{G}$ for academic, by evaluating the variables in vector $\mathrm{X}$ at their sample means (and therefore by setting these variables to zero). This gap - reported in Table 7 - measures the difference in outcomes between vocational and academic education relative to the

\footnotetext{
${ }^{16}$ For some individuals who have temporarily left the survey, the previous survey could be earlier than for the individuals who reply to all successive surveys. We have estimated equation (1) by eliminating the individuals who are present only in an intermitted way, with no qualitative changes of results. These findings are available from the authors upon request.

${ }^{17}$ We have experimented with a conditional logit specification, with no qualitative change in results.
} 
difference at age 23, separately for lower and higher education. ${ }^{18}$ The table has two key messages: a) the outcome gap between vocational and academic education differs across education levels; b) for both wages and employment, the estimated gap is negative and often statistically significant, suggesting that, if any positive advantage exists at age 23 in favour of vocational education, this advantage declines as age (time) goes by.

We estimate parameters $\beta_{0}+\beta_{\mathrm{V}}$ and $\beta_{0}+\beta_{\mathrm{G}}$ for each education level using the AIPW method described in the Appendix and report in Table 8 the estimated average treatment effects at age 23 for the four outcomes under study. In the bottom part of the table we show the differences between the estimated parameters for vocational and academic education, both for lower and for higher education. ${ }^{19}$ For employment, our evidence indicates that no significant difference exists in the case of lower education. In contrast, there is a substantial premium in favour of vocational higher education (18.5 percentage points). Part of this premium is driven by our inclusion in the final data of those still in full time education (close to 2 percent of total observations). Even excluding this group, however, the gap remains large (16.8 percentage points) and statistically significant. ${ }^{20}$

For wages, the estimated initial gap in favour of those with vocational education is close to 10 percent, independently of the level of education, reflecting the fact that those with vocational education have longer labour market experience at age 23. While we find no evidence of a difference in the probability of adding additional qualifications between age 23 and age 33 , there is evidence that those with vocational education are less likely to be involved in training between these ages, especially when education is lower.

We put together the evidence presented in the last two tables by showing in Table 9 the estimated vertical distance between profiles, $\pi_{\mathrm{jV}}+\beta_{\mathrm{V}}-\pi_{\mathrm{jG}}-\beta_{\mathrm{G}}$, for any available age in the range 23 to 55. Consider first employment. For lower education, there is no evidence that those with vocational education have any initial or later advantage over those with academic education.

${ }^{18}$ Consider the two treatments $s$ and $s^{\prime}$ and assume that $\beta_{\mathrm{s}}>\beta_{\mathrm{s}^{\prime}}$, suggesting that the selected outcome at the initial age and conditional on $\mathrm{X}$ is higher for the former treatment. The estimated gap $\pi_{\mathrm{js}}-\pi_{\mathrm{ls}^{\prime}}>0$ is informative of whether this advantage increase with age (time). To see why, at age 50 the difference in expected outcomes between the two treatments at mean levels of $\mathrm{X}$ is given by

$$
\left[E\left(Y_{\text {is }} \mid X=0, A_{i}=50\right)-E\left(Y_{\text {is }} \mid X=0, A_{i}=23\right)\right]-\left[E\left(Y_{\text {is }^{\prime}} \mid X=0, A_{i}=50\right)-E\left(Y_{\text {is' }} \mid X=0, A_{i}=23\right)\right]=\pi_{50 s}-\pi_{50 s^{\prime}}
$$

which is larger than the initial advantage if $\pi_{50 \mathrm{~s}}-\pi_{50 \mathrm{~s}^{\prime}}>0$.

19 The estimation of parameters $\beta$ are necessary to understand whether the eventual initial advantage associated to vocational education turns into a disadvantage as time goes by. For instance, a disadvantage at age 50 implies that

$$
\left[\mathrm{E}\left(\mathrm{Y}_{\mathrm{is}} \mid \mathrm{X}=0, \mathrm{~A}_{\mathrm{i}}=50\right)-\left[\mathrm{E}\left(\mathrm{Y}_{\mathrm{is}} \mid \mathrm{X}=0, \mathrm{~A}_{\mathrm{i}}=50\right)=\pi_{50 \mathrm{~s}}+\beta_{\mathrm{s}}-\pi_{50 \mathrm{~s}^{\prime}}-\beta_{\mathrm{s}^{\prime}}<0\right.\right.
$$

${ }^{20}$ Results available from the authors upon request. 
For those with higher education, however, the high initial advantage enjoyed at age 23 by those with a vocational education disappears almost entirely by age 33 and remain positive, small and not statistically significant until age 55 .

These estimates suggest that the view that vocational education provides a temporary advantage that decreases with age holds only for the better educated, a minority of the individuals in these data. The initial advantage, however, never turns into a later disadvantage. Figure 1 illustrates the employment profiles by age and educational attainment, showing that: a) the probability of employment for those with higher vocational education is always higher than for those with higher academic education; b) average employment probabilities are very similar across education levels and decline with age.

Turning to real net wages, we find that the initial 10 percent advantage enjoyed by those with lower vocational education with respect to the comparison group with academic education turns into a disadvantage from age 33 to 46. After that age, there is no statistical difference in real net wages between the two groups. Since the individuals born in 1958 have turned 50 at the outset of the Great Recession, these results suggest that those with lower vocational education have performed relatively well both in terms of employment and in terms of wage in the presence of the large negative macroeconomic shock, which seems to be in contrast with the view that those with this type of education are less capable to adjust in the presence of negative economic shocks.

In the case of higher education, the initial advantage enjoyed by those with vocational education completely disappears by age 33 and remains small and not statistically different from zero at later ages. Figure 2 illustrates the wage profiles by age and education, and confirms that only individuals with lower vocational education face a clear trade-off between early wage advantages and later wage disadvantages when compared to individuals with lower academic education.

Individuals can compensate their lack of qualifications at age 23 by acquiring new qualifications or by undergoing work related training during their working life. As documented in the third column of Table 9 and in Figure 3, there is no evidence in our data that the type of educational qualification affects in a statistically significant way the probability of acquiring new qualifications. There is evidence, however, that those with lower vocational education are less likely to be involved in work related training, especially in the first part of their working career (see column (4) of Table 9 and Figure 4), in line with the view that their accumulated skills can be readily spent in the labour market.

We combine the results on employment and wages by age and education type by computing for each group the expected long-term earnings at age 23, using the estimated parameters 
reported in Tables 7 to 9. Since our data only contain information for six age points, we linearly interpolate between each pair of points to obtain expected employment and net wages at each age, and use these values to compute (2) for each treatment group. The first column in Table 10 reports our estimates.

We find that expected long-term net earnings at age 23 (and until age 55) are equal to about 311,4 thousand pounds (at 2005 prices) for those with lower vocational education and to about 328,1 thousand pounds for those with lower academic education, implying that the former group earns in expected terms about 5 percent less than the latter group until age 55 . This negative difference - statistically significant at the 10 percent level of confidence - contrasts with the initial advantage enjoyed at age 23 by those with lower vocational education (12,1 versus 11,1 thousand pounds, obtained as the product of the expected probability of employment and expected real net wages), suggesting the presence of a trade - off between early relative benefits and later relative costs, with the former outweighed by the latter.

In an effort to capture the variability of earnings over the life cycle, we compute the coefficient of variation of real net wages by age and education type and find that, conditional on age effects, this indicator is about 20 percent lower for those with lower vocational education than for their comparison group with academic education. On the other hand, the coefficient of variation for employment - equal $\sqrt{(1-\mathrm{p}) / \mathrm{p}}$, where $p$ is mean employment - does not vary much between lower vocational and academic types, as documented by the left panel of Figure 1 . The combination of lower expected long-term earnings with the lower variability of earnings over the life cycle suggests caution in drawing conclusion for this group of individuals, because the lower earnings risk may more than compensate in utility terms the lower expected long-term earnings.

Turning to the group with higher education (NVQ levels 4 and 5) we estimate that expected long-term earnings are equal to about 388,5 thousand pounds in the case of vocational education and to about 363,7 thousand pounds for academic education. Contrary to the case of lower education, higher vocational education for this cohort pays better ( +6.8 percent) over the years than higher academic education, ${ }^{21}$ with the relative advantage being almost entirely frontloaded near labour market entry. We also compute for this group the coefficient of variation of real net wages and find that it is close to 17 percent lower for those with vocational education. To this one should add the lower coefficient of variation of employment for the vocationally educated, which can be inferred directly from the right hand panel in Figure 1. The combination of higher returns and lower risk suggests that for the cohort of individuals born in 1958 higher vocational

\footnotetext{
${ }^{21}$ Notice however that the estimated difference between long-term earnings is not statistically significant at the conventional levels.
} 
education did somewhat better in the long run than higher academic education, in contrast with the common view that it should do worse.

\section{2 "Dominant" and "Non - dominant" vocational education}

We have defined education types in NCDS using the highest attained qualification at age 23. Yet we have shown in Section 2 that individuals with the same highest qualification may differ in the bundle of qualifications held, part of them vocational and part academic. In particular, we have distinguished between dominant and non dominant education types, the key difference being that in dominant types the difference in NVQ levels between the highest vocational (academic) qualification and the highest academic (vocational) qualification is at least equal to two, and in non dominant types it is lower than two. In other words, non dominant types have a more balanced composition of qualifications.

We have also shown in Table 3 that in NCDS data academic education and higher vocational education are mostly of the dominant type, with only a small minority of individuals belonging to the non dominant category. In contrast, lower vocational education is characterized by a higher presence of non dominant profiles (about 35 percent). We therefore distinguish between these two types only for lower vocational education - which we divide in two groups - V1 dominant (V1F) and V1 non dominant (V1C), while retaining the usual classification for the other treatments. We use fixed effects and AIPW estimates in this extended model with six treatments and report our key results in Table 11. In this table, we show the estimated vertical distance between treatment V1F and treatment G1, between treatment V1C and treatment G1 and finally between the two vocational treatments. We complement this evidence with Figures 5 and 6, which plot the employment and net wages profiles for the three treatments associated to lower education.

For employment, we find that non-dominant vocational education performs generally better than the dominant type, although the difference is rarely statistically significant, as it happens at age 42, when we register a negative gap in employment probabilities equal to 4.5 percentage points - statistically significant at the 10 percent level of confidence. For net wages, estimated differences between V1F and V1C are small and statistically significant - at 10 percent - only at age 23. There is also evidence that the V1F group invests less in additional qualifications and in additional training. The last column of Table 10 reports the expected lifetime earnings for the two groups, that we estimate at about 310,5 thousand pounds for those with dominant vocational education and at about 319,5 thousand pounds for those with a non dominant profile. We 
conclude that having a more balanced composition of skills is associated to a small (2.9 percent) premium in long-term earnings.

\section{Results using BCS}

The empirical results presented in the previous section are based on NCDS data, and therefore refer to a single cohort. The natural question to ask is whether they hold for other cohorts as well. To investigate this, we consider in this section the younger cohort of individuals born in 1970. Using BCS data and the rich information on attained qualifications, we are able to estimate for each individual the highest qualification (vocational or academic) held by age 23, and to follow him from 1996 to 2012, a shorter period than NCDS that entirely overlaps the latter. ${ }^{22}$

During this overlap, the two cohorts faced similar demand shocks but substantially different supply conditions. First of all, while the NCDS cohort went to school in a period when the selective system based on grammar schools, secondary moderns and selection at age 11 (the so called "11 plus system") - was being phased out and replaced by a more comprehensive system characterized by later selection (see Galindo-Rueda and Vignoles, 2004), the BCS cohort was educated after the transition from the former to the latter system had been completed in the majority of Local Education Authorities. ${ }^{23}$ Second, the younger cohort went to school during a period of widening wage differentials between graduates and non-graduates (see Blanden and Machin, 2004), when the distinction between polytechnics and universities was substantially reduced. These changes are at the root of the remarkable education expansion experienced by the cohorts born between 1970 and 1975 and documented by Walker and Zhu, 2008, and Devereux and Fen, 2011.

\subsection{The life cycle pattern of employment and wages}

We estimate equation (1) when the outcome variable is either the probability of employment or real net annual wages. For both outcomes we estimate a specification that includes the interactions of age with parental background and ability controls, which in the case of BCS include: individual math and reading tests scores at age 10, the mother's employment status in 1980, the father's social status, household gross weekly income in 1980, the mother's height and age at birth, parental education and the individual's weight at birth.

\footnotetext{
${ }^{22}$ Notice that the initial age when wages and employment are observed is 26, not 23.

23 In the ten years between 1965 and 1975, virtually all state secondary schools in Wales and Scotland went comprehensive. In England the figure was about 90 per cent.
} 
As for NCDS, we combine the fixed effects and the AIPW estimates and report the estimated vertical distance between employment and wage profiles $\pi_{\mathrm{jV}}+\beta_{\mathrm{V}}-\pi_{\mathrm{jG}}-\beta_{\mathrm{G}}$ in Table 12 . We also plot employment and wage profiles in Figures 7 and 8 . As in the previous section, we distinguish between lower and higher education. In the former case, we find no evidence of statistically significant differences in either wages or employment between those with vocational and academic education, with the single exception of employment at age 26 , which shows a small positive premium (2.6 percentage points - statistically significant at the 10 percent level of confidence) in favour of vocational education. There is also no statistically significant difference in the coefficients of variation of real net wages. ${ }^{24}$

In sharp contrast, we find that individuals with higher vocational education have an early employment advantage with respect to those with higher academic education (5.6 percentage points). This advantage, however, disappears entirely by age 30 . We also find that higher vocational education is always associated to lower earnings than academic education, with a small gap at age 26 (2.5 percent) that widens with age, reaching 14.2 percent at age 38 . As in the case of lower education, we find no evidence that the coefficient of variation of real net earnings is statistically different between the two groups. For this group, our evidence clearly support the view that the initial (employment) advantage associated to vocational education decreases with age.

Column (2) in Table 13 reports our estimates of the expected discounted sum of real earnings - weighted by the probability of employment - from age 26 to age 42, using BCS data. Clearly, this is only a partial snapshot of lifetime earnings, as we exclude the years from the early 40s to the mid-50s. We find that those with lower vocational education are expected to earn about as much as those with lower academic education (228,9 versus 227,1 thousand pounds). On the other hand, those with higher vocational education earn from age 26 to age 42 about 9 percent less than those with higher academic education (286,2 versus 315,1 thousand pounds, a statistically significant gap), in spite of the early small advantage at age 26 - 12,6 rather and 12,1 thousand pounds respectively, a 4 percent premium driven by the initial employment premium. These estimates suggest that for the group with higher vocational education short term advantages in employability go hand in hand with lower earnings in the medium term with respect to the comparison group with higher academic education.

Table 13 also reports in column (3) expected earnings by treatment for individuals with dominant and non - dominant lower vocational education. We find that the latter group enjoys a 12 percent premium in terms of the discounted sum of earnings from age 26 to age 42, much higher than the premium found using NCDS (2.9 percent). The estimated gap is statistically

\footnotetext{
${ }^{24}$ The estimates for the coefficient of variation of real earnings is available from the authors upon request.
} 
significant. For the sake of comparison between cohorts, we also report in the first column of the table the discounted sum of expected earnings from age 26 to 42 for the NCDS sample, using the estimates discussed in the previous section.

A clear message of the table is that the relative labour market performance of vocational and academic education varies not only by education level - as discussed at length in these pages but also by cohort. In particular, we show that lower vocational education performs relatively better for the younger cohort, and higher vocational education performs relatively better for the older cohort. These important differences between cohorts clearly warns against using empirical strategies that rely on between-cohort variation.

The between - cohort changes in relative long-term earnings can be easily interpreted using the framework of relative demand and supply by education level - see for instance Card and Lemieux, 2001. On the one hand, the relative earnings of those with lower vocational education have increased for the younger cohort, in line with a decline in relative supply, documented in Table 2. On the other hand, the decline in relative earnings experienced by the younger cohort with higher vocational education is also consistent with its higher relative supply.

\section{Discussion and Conclusions}

We have investigated the view that vocational education provides in the short run a smoother transition from school to work at the price of faster depreciation of accumulated skills, lower earnings growth and even premature exit from active labour force in the medium and long run. This analysis faces several difficulties, including the self-sorting of individuals into alternative education paths and the changing contents of vocational and academic education across different cohorts of individuals.

To address these problems, long longitudinal data that follow individuals over important portions of their labour market careers are essential. We have used data from two UK cohort studies, the NCDS for the cohort born in 1958 and the BCS for the cohort born 12 years later, that are very rich of information on individual education, measured ability and early life characteristics. Due to the relatively large sample sizes, we have been able to distinguish between vocational and academic education for two different education levels, upper secondary (NVQ 2/3) and tertiary education (NVQ 4/5).

Our estimates indicate that vocational education offers better employment prospects at the beginning of an individual career only to those with higher education level. At lower levels, such advantage is either non - existent or small and not statistically significant. As individuals progress

in their labour market careers, this initial advantage is rapidly eroded, but never turns into a 
disadvantage. Although the probability of employment associated to vocational education may decline with age, it always remain at least as high as the probability associated to a more academic curriculum, suggesting that no trade off exists between short term employment advantages and long term employment disadvantages.

The reason why we do not find evidence of an employment trade-off associated to vocational education could simply be that individuals with this education type compensate the progressive depreciation of their skills with additional investments in educational qualifications and work related training. Yet we find that this is not the case, and that workers with vocational education do not acquire more off-the-job education or training than comparable workers with academic education.

The lack of an employment trade-off may also be due to the fact that skill depreciation for those with vocational education affects mainly their wages. Therefore, rather than an employment trade-off, one should look for a wages trade-off. We investigate the life cycle pattern of real net wages by education type and find mixed results, that vary by cohort and level of education. For the older cohort, we find evidence that an early advantage in wages turns into a later disadvantage only for those with lower education. For the younger cohort, those with higher vocational education have lower real net earnings than those with academic education both early and later on in their career. For the remaining two groups - the older cohort with higher education and the younger cohort with lower education - the absence of an employment tradeoff extends also to the real net wage.

We hasten to stress that the presence of trade-offs between short run and long run benefits does not necessarily imply that individuals who have invested in vocational education have lower expected lifetime utility than individuals who have taken up academic education. Two key ingredients of this utility are expected lifetime earnings and the coefficient of variation of earnings. For lower education, these indicators suggest that individuals with vocational education are not clearly worse off than individuals with academic education. For higher education, results differ sharply across cohorts: while the older cohort is slightly better off with vocational education, the younger cohort is clearly worse off, mainly because of the unfavourable life cycle pattern of wages. 


\section{Tables and Figures}

Table 1. Expected long-term earnings. Vocational relative to academic education. By education level and cohort.

\begin{tabular}{lll}
\hline & NCDS & BCS \\
\hline Lower education & Lower & As high \\
Higher education & Higher & Lower \\
\hline
\end{tabular}

Table 2. Distribution of highest educational qualifications at age 23. Males. NCDS 1981 and BCS 2000.

\begin{tabular}{lcc}
\hline & NCDS & BCS \\
\hline Low education & $1,930(36.0)$ & $1,292(27.1)$ \\
Vocational level - low (NVQ 2-3) & $1,723(32.2)$ & $1,081(22.7)$ \\
Academic level - low (NVQ 2-3) & $744(13.9)$ & $1,111(23.3)$ \\
Vocational level - high (NVQ 4-5) & $270(5.0)$ & $435(9.1)$ \\
Academic level - high (NVQ 4-5) & $691(12.9)$ & $852(17.9)$ \\
Total & 5,358 & 4,771 \\
Percent who left school at 16 or under & 70.2 & 61.4 \\
\hline
\end{tabular}

Table 3. Percent with "dominant" academic or vocational qualifications at age 23. Males. NCDS 1981 and BCS 1999.

\begin{tabular}{lcc}
\hline & NCDS & BCS \\
\hline Vocational level NVQ 2-3 (V1) & 64.9 & 45.7 \\
Academic level NVQ 2-3 (G1) & 86.0 & 77.7 \\
Vocational level NVQ 4-5 (V2) & 80.4 & 69.5 \\
Academic level NVQ 4-5 (G2) & 98.1 & 85.1 \\
\hline
\end{tabular}


Table 4. Means and standard deviations of employment, wages and ability. By education type.

NCDS 1981-2013

\begin{tabular}{lccccc}
\hline & $\begin{array}{c}\text { Low } \\
\text { education }\end{array}$ & $\begin{array}{c}\text { Vocational } \\
\text { low }\end{array}$ & $\begin{array}{c}\text { Academic } \\
\text { low }\end{array}$ & $\begin{array}{c}\text { Vocational } \\
\text { high }\end{array}$ & $\begin{array}{c}\text { Academic } \\
\text { high }\end{array}$ \\
\hline \multirow{2}{*}{ Probability of employment } & & & & & \\
& 82.91 & 91.77 & 91.75 & 93.48 & 90.13 \\
Real annual net wages & $(37.6)$ & $(27.5)$ & $(27.5)$ & $(24.7)$ & $(29.8)$ \\
& 14,415 & 17,155 & 19,804 & 21,342 & 23,838 \\
Any qualification since previous interview & $(7,335)$ & $(8,884)$ & $(12,137)$ & $(12,501)$ & $(13,917)$ \\
& 17.76 & 21.05 & 25.85 & 28.04 & 27.74 \\
Any training since previous interview & $(38.22)$ & $(40.77)$ & $(43.79)$ & $(44.93)$ & $(44.78)$ \\
& 24.91 & 29.07 & 39.19 & 41.23 & 36.64 \\
Math test score at 7 & $(43.25)$ & $(45.41)$ & $(48.82)$ & $(49.24)$ & $(48.18)$ \\
& 0.39 & 0.47 & 0.55 & 0.59 & 0.61 \\
\end{tabular}

BCS 1996-2012

\begin{tabular}{lccccc}
\hline & $\begin{array}{c}\text { Low } \\
\text { education }\end{array}$ & $\begin{array}{c}\text { Vocational } \\
\text { low }\end{array}$ & $\begin{array}{c}\text { Academic } \\
\text { low }\end{array}$ & $\begin{array}{c}\text { Vocational } \\
\text { high }\end{array}$ & $\begin{array}{c}\text { Academic } \\
\text { high }\end{array}$ \\
\hline & & & & & \\
Probability of employment & 82.60 & 92.44 & 93.30 & 95.66 & 93.96 \\
Real annual net wages & $(37.9)$ & $(26.4)$ & $(24.9)$ & $(20.4)$ & $(23.8)$ \\
& 16,216 & 18,722 & 20,190 & 23,985 & 26,412 \\
& $(10,297)$ & $(15,302)$ & $(19,168)$ & $(24,646)$ & $(23,056)$
\end{tabular}

Note: standard deviations within parentheses.

Table 5. Means and standard deviations of employment and gross real wages. By education type. "Dominant" and "non-dominant" vocational education. NCDS 1981-2013

\begin{tabular}{lcc}
\hline & Employment & Real net wages \\
\hline & & \\
Dominant vocational - low & 91.32 & 16,931 \\
& $(28.1)$ & $(8,739)$ \\
Non dominant vocational - low & 93.75 & 17,606 \\
& $(24.2)$ & $(9,625)$ \\
\hline
\end{tabular}


Table 6. Attrition from the NCDS sample. Probability of leaving the sample in the last two, three, four and five waves. Marginal effects from probit estimates.

\begin{tabular}{|c|c|c|c|c|c|}
\hline & $\begin{array}{c}(1) \\
\text { Last } 2 \text { waves }\end{array}$ & $\begin{array}{c}\text { (2) } \\
\text { Last } 3 \\
\text { waves } \\
\end{array}$ & $\begin{array}{c}\text { (3) } \\
\text { Last } 4 \\
\text { waves } \\
\end{array}$ & $\begin{array}{c}\text { (4) } \\
\text { Last } 5 \\
\text { waves } \\
\end{array}$ & $\begin{array}{c}(6) \\
\text { Last } 2 \text { to last } 5 \\
\text { waves }\end{array}$ \\
\hline Academic low (G1) & $\begin{array}{l}-0.170 \\
(0.133)\end{array}$ & $\begin{array}{c}-0.252^{* *} \\
(0.107)\end{array}$ & $\begin{array}{l}-0.162 \\
(0.104)\end{array}$ & $\begin{array}{c}-0.399 * * * \\
(0.090)\end{array}$ & $\begin{array}{c}-0.263 * * * \\
(0.062)\end{array}$ \\
\hline Academic high (G2) & $\begin{array}{l}-0.125 \\
(0.145)\end{array}$ & $\begin{array}{c}-0.502^{* * *} \\
(0.134)\end{array}$ & $\begin{array}{c}-0.236^{*} \\
(0.123)\end{array}$ & $\begin{array}{c}-0.350 * * * \\
(0.101)\end{array}$ & $\begin{array}{c}-0.343 * * * \\
(0.073)\end{array}$ \\
\hline Vocational low (V1) & $\begin{array}{l}-0.075 \\
(0.087)\end{array}$ & $\begin{array}{c}-0.333 * * * \\
(0.075)\end{array}$ & $\begin{array}{c}-0.220 * * * \\
(0.072)\end{array}$ & $\begin{array}{c}-0.356^{* * *} \\
(0.060)\end{array}$ & $\begin{array}{c}-0.215^{* * *} \\
(0.042)\end{array}$ \\
\hline Vocational high (V2) & $\begin{array}{c}-0.478^{* *} \\
(0.227)\end{array}$ & $\begin{array}{c}-0.381^{* *} \\
(0.161)\end{array}$ & $\begin{array}{l}-0.222 \\
(0.149)\end{array}$ & $\begin{array}{c}-0.366^{* * *} \\
(0.125)\end{array}$ & $\begin{array}{c}-0.303 * * * \\
(0.092)\end{array}$ \\
\hline Constant & $\begin{array}{c}-1.709 * * * \\
(0.227)\end{array}$ & $\begin{array}{c}-0.958^{* * *} \\
(0.192)\end{array}$ & $\begin{array}{c}-1.122^{* * *} \\
(0.193)\end{array}$ & $\begin{array}{c}-0.900 * * * \\
(0.161)\end{array}$ & $\begin{array}{c}-0.616^{* * *} \\
(0.113)\end{array}$ \\
\hline Observations & 2,873 & 3,009 & 3,073 & 3,454 & 6,142 \\
\hline p-value test $\mathrm{G} 1=\mathrm{V} 1$ & 0.462 & 0.452 & 0.574 & 0.628 & 0.434 \\
\hline p-value test $G 2=V 2$ & 0.137 & 0.498 & 0.934 & 0.902 & 0.688 \\
\hline p-value test $\mathrm{G} 1=\mathrm{V} 2$ & 0.192 & 0.442 & 0.700 & 0.804 & 0.676 \\
\hline p-value test $\mathrm{G} 2=\mathrm{V} 1$ & 0.723 & 0.202 & 0.895 & 0.948 & 0.066 \\
\hline
\end{tabular}

Note: each regression includes measured ability at ages 7 and 11 and indicators of early life conditions. In the last column we consider attrition in the last 2, 3, 4 and 5 waves. Robust standard errors within parentheses.

Table 7. Estimated gap $\pi_{\mathrm{jV}}-\pi_{\mathrm{jG}}$ based on fixed effect estimates. Low and high education. Males. NCDS.

\begin{tabular}{lccccc}
\hline & $\begin{array}{c}\text { Employment } \\
\text { status }\end{array}$ & $\begin{array}{c}\text { Log real } \\
\text { net wages }\end{array}$ & $\begin{array}{c}\text { Log real } \\
\text { gross wages }\end{array}$ & $\begin{array}{c}\text { Any } \\
\text { additional } \\
\text { qualification }\end{array}$ & $\begin{array}{c}\text { Any } \\
\text { training }\end{array}$ \\
\hline V1-G1 age=33 & -0.004 & $-0.167^{* * *}$ & $-0.234^{* * *}$ & & \\
V1-G1 age=42 & -0.01 & $-0.228^{* * *}$ & $-0.278^{* * *}$ & 0.005 & 0.05 \\
V1-G1 age=46 & -0.015 & $-0.234^{* * *}$ & $-0.266^{* * *}$ & 0.038 & $0.118^{* * *}$ \\
V1-G1 age=50 & -0.003 & $-0.104^{* *}$ & $-0.168^{* * *}$ & -0.007 & $0.124^{* * *}$ \\
V1-G1 age=55 & -0.005 & $-0.073^{*}$ & $-0.112^{* *}$ & -0.02 & $0.184^{* * *}$ \\
V2-G2 age=33 & $-0.164^{* * *}$ & $-0.144^{* * *}$ & $-0.151^{* * *}$ & - & - \\
V2-G2 age=42 & $-0.17^{* * *}$ & -0.087 & $-0.134^{* *}$ & 0.055 & 0.065 \\
V2-G2 age=46 & $-0.155^{* * *}$ & $-0.111^{* *}$ & $-0.099^{*}$ & $0.119^{* *}$ & 0.078 \\
V2-G2 age=50 & $-0.148^{* * *}$ & -0.072 & -0.091 & 0.064 & 0.024 \\
V2-G2 age=55 & $-0.149^{* * *}$ & -0.078 & $-0.151^{* *}$ & 0.060 & 0.079 \\
& & & & & \\
\hline
\end{tabular}

Note: ${ }^{* *}, * *, *$ for statistical significance at the 1,5 and 10 percent level of confidence. 
Table 8. Estimated effects of $\beta_{\mathrm{V}}$ and $\beta_{\mathrm{G}}$ using AIPW estimates. Males. NCDS.

\begin{tabular}{|c|c|c|c|c|}
\hline & $\begin{array}{l}\text { Employment } \\
\text { status }\end{array}$ & $\begin{array}{c}\text { Log real } \\
\text { net } \\
\text { wages }\end{array}$ & $\begin{array}{c}\text { Any } \\
\text { additional } \\
\text { qualification } \\
\text { from age } 23 \\
\text { to age } 33\end{array}$ & $\begin{array}{c}\text { Any } \\
\text { training } \\
\text { from age } \\
23 \text { to age } \\
33\end{array}$ \\
\hline Vocational low V1 - age 23 & $\begin{array}{c}0.889 * * * \\
(0.010)\end{array}$ & $\begin{array}{c}9.217^{* * *} \\
(0.010)\end{array}$ & $\begin{array}{c}0.414 * * * \\
(0.019)\end{array}$ & $\begin{array}{c}0.474 * * * \\
(0.019)\end{array}$ \\
\hline Academic low G1 - age 23 & $\begin{array}{c}0.886^{* * *} \\
(0.013)\end{array}$ & $\begin{array}{c}9.117^{* * *} \\
(0.016)\end{array}$ & $\begin{array}{c}0.419^{* * *} \\
(0.024)\end{array}$ & $\begin{array}{c}0.613^{* * *} \\
(0.024)\end{array}$ \\
\hline Vocational high V2 - age 23 & $\begin{array}{c}0.917^{* * *} * \\
(0.018)\end{array}$ & $\begin{array}{c}9.189^{* * *} \\
(0.020)\end{array}$ & $\begin{array}{c}0.500 * * * \\
(0.034)\end{array}$ & $\begin{array}{c}0.617 * * * \\
(0.039)\end{array}$ \\
\hline Academic high G2 - age 23 & $\begin{array}{c}0.732^{* * *} \\
(0.030)\end{array}$ & $\begin{array}{c}9.081 * * * \\
(0.021)\end{array}$ & $\begin{array}{c}0.549 * * * \\
(0.040)\end{array}$ & $\begin{array}{c}0.660^{* * *} \\
(0.033)\end{array}$ \\
\hline $\begin{array}{l}\text { difference V1-G1 } \\
\text { difference V2-G2 }\end{array}$ & $\begin{array}{c}0.004 \\
0.185^{* * *}\end{array}$ & $\begin{array}{l}0.100^{* * *} \\
0.108^{* * *}\end{array}$ & $\begin{array}{l}-0.005 \\
-0.049\end{array}$ & $\begin{array}{c}-0.139 * * * \\
-0.042\end{array}$ \\
\hline
\end{tabular}

Note: $* * *, * *, *$ for statistical significance at the 1,5 and 10 percent level of confidence.

Table 9. Vertical distance between profiles $\pi_{\mathrm{jV}}+\beta_{\mathrm{V}}-\pi_{\mathrm{jG}}-\beta_{\mathrm{G}}$, based on fixed effects and AIPW estimates. Males. NCDS.

\begin{tabular}{lcccc}
\hline & $\begin{array}{c}\text { Employment } \\
\text { status }\end{array}$ & $\begin{array}{c}\text { Log real net } \\
\text { wages }\end{array}$ & $\begin{array}{c}\text { Any } \\
\text { additional } \\
\text { qualification }\end{array}$ & Any training \\
\hline V1-G1 age=23 & 0.004 & $0.100 * * *$ & - & - \\
V1-G1 age=33 & -0.000 & $-0.067 * *$ & -0.005 & $-0.139 * * *$ \\
V1-G1 age $=42$ & -0.006 & $-0.128^{* *}$ & 0.000 & $-0.089 * * *$ \\
V1-G1 age $=46$ & -0.011 & $-0.134 * * *$ & 0.033 & -0.021 \\
V1-G1 age $=50$ & 0.001 & -0.004 & -0.012 & -0.015 \\
V1-G1 age $=55$ & -0.001 & 0.027 & -0.025 & 0.045 \\
V2-G2 age $=23$ & $0.185 * * *$ & $0.108 * * *$ & - & - \\
V2-G2 age $=33$ & 0.021 & -0.036 & -0.049 & -0.042 \\
V2-G2 age $=42$ & 0.015 & 0.021 & 0.006 & 0.023 \\
V2-G2 age $=46$ & 0.030 & -0.003 & 0.070 & 0.036 \\
V2-G2 age $=50$ & 0.037 & 0.036 & 0.015 & -0.018 \\
V2-G2 age $=55$ & 0.036 & 0.030 & 0.011 & 0.037
\end{tabular}

Note: ${ }^{* * *}, * *, *$ for statistical significance at the 1,5 and 10 percent level of confidence. The standard errors are bootstrapped with 250 replications. 
Table 10. Expected long-term earnings at age 23 by treatment. Males. NCDS.

NCDS age 23-55 NCDS dominant and non-

dominant lower voc.edu.

\begin{tabular}{lll}
\hline lower vocational V1 & 311,400 & \\
lower academic G1 & $(20,146)$ & \\
& 328,125 & \\
higher vocational V2 & $(22,390)$ & \\
& 388,491 & \\
higher academic G2 & $(31,113)$ & 310,526 \\
& 363,721 & $(26,289)$ \\
lower vocational V1F & $(29,084)$ & 319,482 \\
lower vocational V1C & & $(26,840)$ \\
& & \\
p-value difference V1-G1 & & \\
p-value difference V2-G2 & & \\
p-value difference V1F-V1C & 0.103 & 0.467 \\
\hline Note & 0.228 & \\
\hline
\end{tabular}

Note: standard errors computed by bootstrapping over 50 replications. Real rate of interest: 0.02 . V1F: dominant; $\mathrm{V} 1 \mathrm{C}=$ non-dominant.

Table 11. Vertical distance between profiles $\pi_{\mathrm{jV}}+\beta_{\mathrm{V}}-\pi_{\mathrm{jG}}-\beta_{\mathrm{G}}$ with dominant and non-dominant low vocational education. Based on fixed effects and AIPW. Males. NCDS.

\begin{tabular}{lcccc}
\hline & $\begin{array}{c}\text { Employment } \\
\text { status }\end{array}$ & $\begin{array}{c}\text { Log real net } \\
\text { wages }\end{array}$ & $\begin{array}{c}\text { Any additional } \\
\text { qualification }\end{array}$ & Any training \\
\hline V1F-G1 age $=23$ & & & & \\
V1F-G1 age $=33$ & -0.006 & $0.125^{* * *}$ & - & - \\
V1F-G1 age $=42$ & -0.030 & $-0.132^{* *}$ & $-0.085^{*}$ & $-0.188^{* * *}$ \\
V1F-G1 age $=46$ & -0.028 & $-0.130^{* * *}$ & -0.048 & -0.094 \\
V1F-G1 age $=50$ & -0.017 & -0.002 & -0.084 & -0.025 \\
V1F-G1 age $=55$ & -0.023 & 0.032 & -0.087 & 0.039 \\
& & & & - \\
V1C-G1 age $=23$ & -0.008 & $0.080^{* * *}$ & - & - \\
V1C-G1 age $=33$ & 0.002 & -0.058 & 0.036 & $-0.080^{* *}$ \\
V1C-G1 age $=42$ & 0.015 & -0.100 & -0.104 & -0.093 \\
V1C-G1 age $=46$ & -0.001 & $-0.116^{* * *}$ & -0.113 & -0.110 \\
V1C-G1 age=50 & 0.013 & 0.016 & 0.135 & 0.082 \\
V1C-G1 age $=55$ & 0.015 & 0.054 & $-0.178^{* * *}$ & 0.028 \\
& & & & - \\
V1F-V1C age=23 & 0.014 & $0.045^{*}$ & - & $-0.108^{* * *}$ \\
V1F-V1C age=33 & -0.018 & 0.006 & $-0.121 * * *$ & -0.001 \\
V1F-V1C age=42 & $-0.045^{*}$ & -0.032 & 0.058 & 0.085 \\
V1F-V1C age=46 & -0.027 & -0.014 & 0.065 & -0.121 \\
V1F-V1C age=50 & -0.030 & -0.018 & $-0.219 * *$ & -0.005 \\
V1F-V1C age=55 & -0.038 & -0.022 & 0.091 & \\
& & & &
\end{tabular}

Note: $* * *, * *, *$ for statistical significance at the 1,5 and 10 percent level of confidence. The standard errors are bootstrapped with 100 replications. 
Table 12. Vertical distance between profiles $\pi_{\mathrm{jV}}+\beta_{\mathrm{V}}-\pi_{\mathrm{jG}}-\beta_{\mathrm{G}}$. Estimates based on fixed effects and AIPW estimates. Males. BCS.

\begin{tabular}{|c|c|c|}
\hline & $\begin{array}{l}\text { Employment } \\
\text { status }\end{array}$ & $\begin{array}{l}\text { Log real net } \\
\text { wages }\end{array}$ \\
\hline V1-G1 age $=26$ & $0.026^{*}$ & 0.016 \\
\hline V1-G1 age $=30$ & 0.013 & 0.004 \\
\hline V1-G1 age $=34$ & 0.004 & -0.002 \\
\hline V1-G1 age $=38$ & 0.015 & -0.027 \\
\hline V1-G1 age $=42$ & 0.019 & -0.013 \\
\hline $\mathrm{V} 2-\mathrm{G} 2$ age $=26$ & $0.056 * * *$ & -0.025 \\
\hline $\mathrm{V} 2-\mathrm{G} 2$ age $=30$ & 0.008 & $-0.109 * * *$ \\
\hline V2-G2 age $=34$ & -0.003 & $-0.109 * *$ \\
\hline V2-G2 age $=38$ & -0.003 & $-0.142 * * *$ \\
\hline V2-G2 age $=42$ & 0.012 & $-0.095^{*}$ \\
\hline
\end{tabular}

Note: $* * *, * * *$ for statistical significance at the 1,5 and 10 percent level of confidence.

Table 13. Expected long-term income by treatment. Males. NCDS and BCS age 26-42.

\begin{tabular}{lccc}
\hline & NCDS age & BCS age 26-42 & $\begin{array}{c}\text { BCS age 26-42 } \\
\text { dominant and } \\
\text { non-dominant } \\
\text { lower voc.edu. }\end{array}$ \\
lower vocational V1 & & & \\
lower academic G1 & 178,778 & 228,973 & \\
& $(9,472)$ & $(3,998)$ & \\
higher vocational V2 & 190,839 & 227,157 & \\
& $(11,198)$ & $(4,126)$ & \\
higher academic G2 & 215,386 & 286,270 & \\
& $(15,431)$ & $(6,831)$ & 214,790 \\
lower vocational V1F & 205,883 & 315,124 & $(5,743)$ \\
& $(14,022)$ & $(6,679)$ & 242,109 \\
lower vocational V1C & & & $(5,280)$ \\
p-value difference V1-G1 & & & \\
p-value difference V2-G2 & 0.054 & 0.753 & 0.000 \\
p-value difference V1F-V1C & 0.437 & 0.002 &
\end{tabular}

Note: standard errors computed by bootstrapping over 50 replications. Real rate of interest: 0.02. V1F: dominant; $\mathrm{V} 1 \mathrm{C}=$ non-dominant. 
Figure 1. Simulated life cycle profile: employment probabilities. Males. NCDS.

\section{Employment}
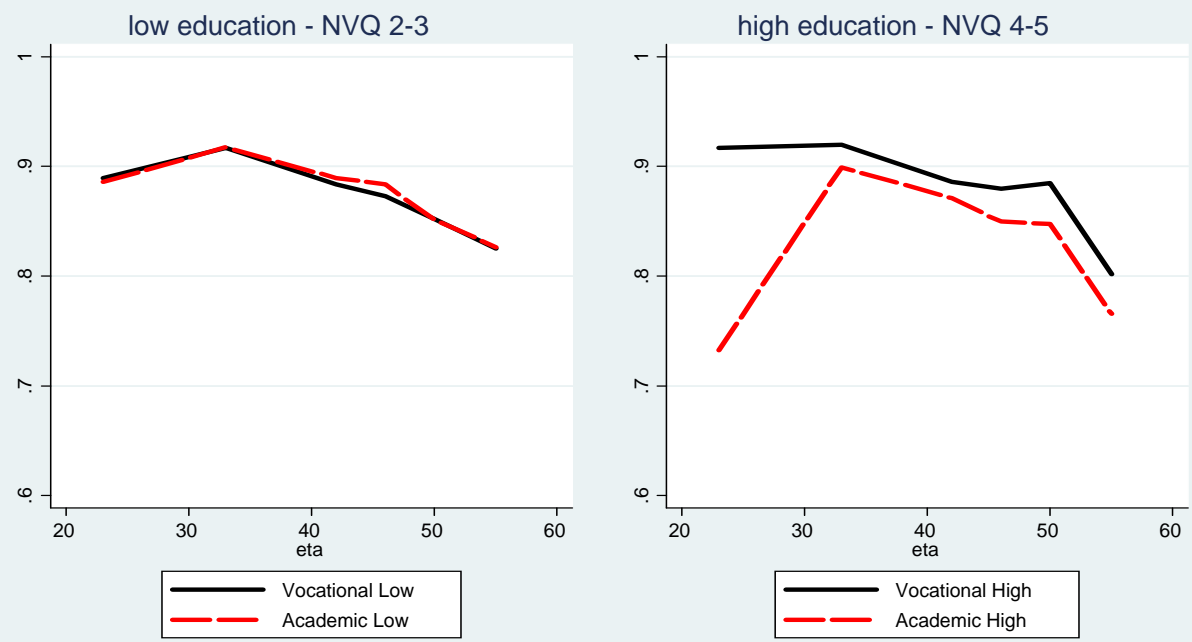

Figure 2. Simulated life cycle profile: real net annual wages. Males. NCDS.

Annual real net wages
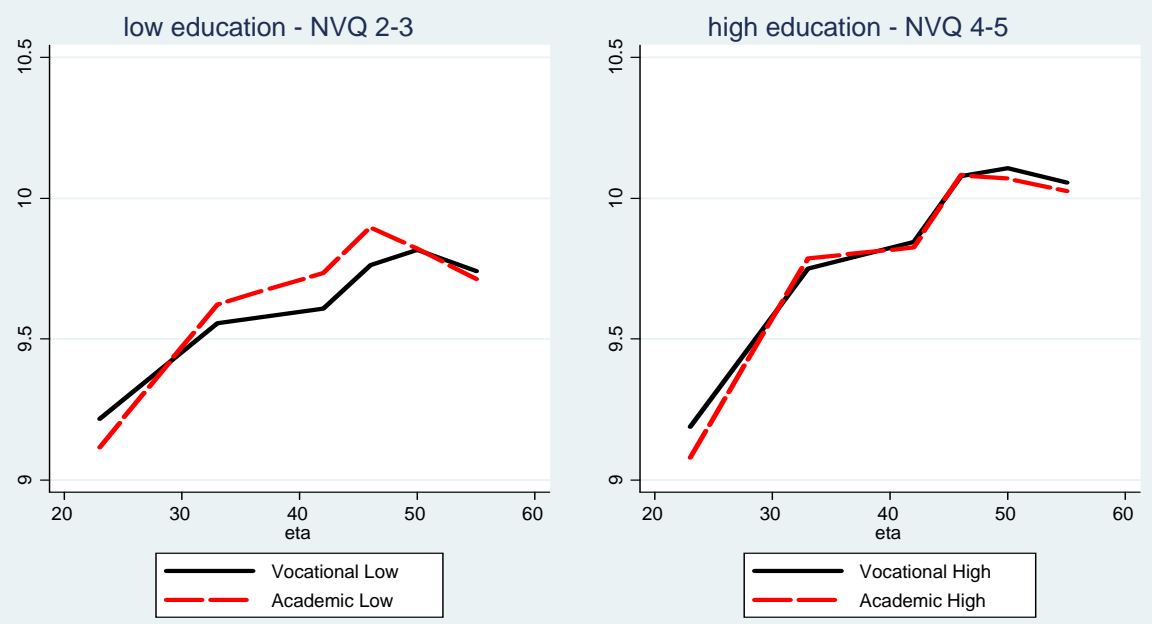
Figure 3. Simulated life cycle profile: additional qualifications. Males. NCDS.

Any qualification age 33-55
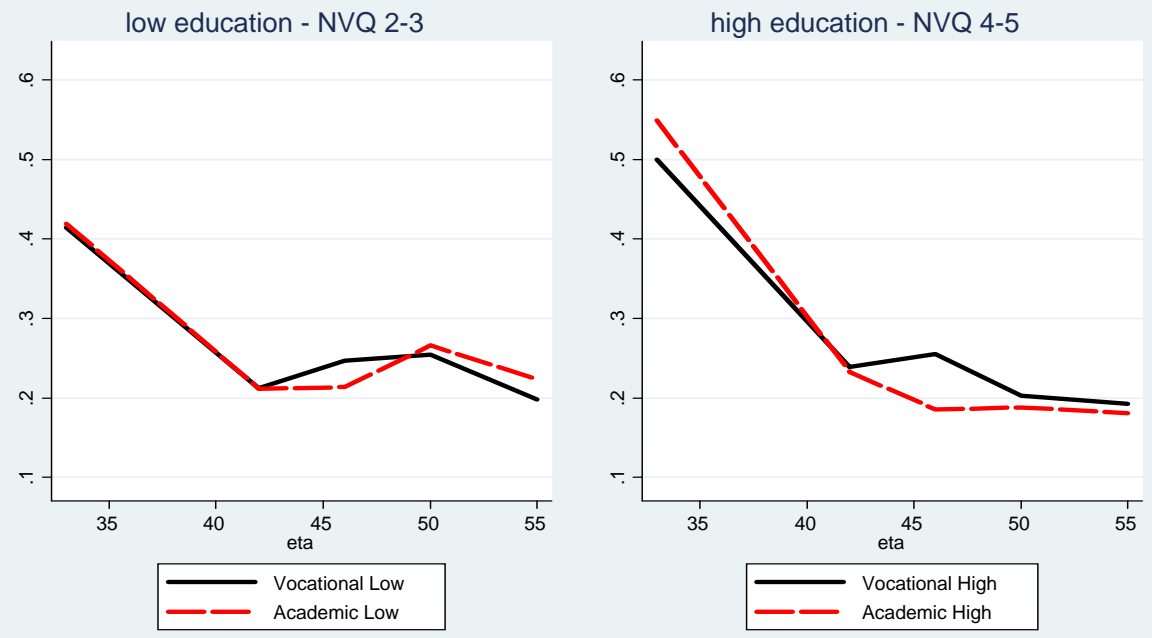

Figure 4. Simulated life cycle profile: additional training. Males. NCDS.

Any training
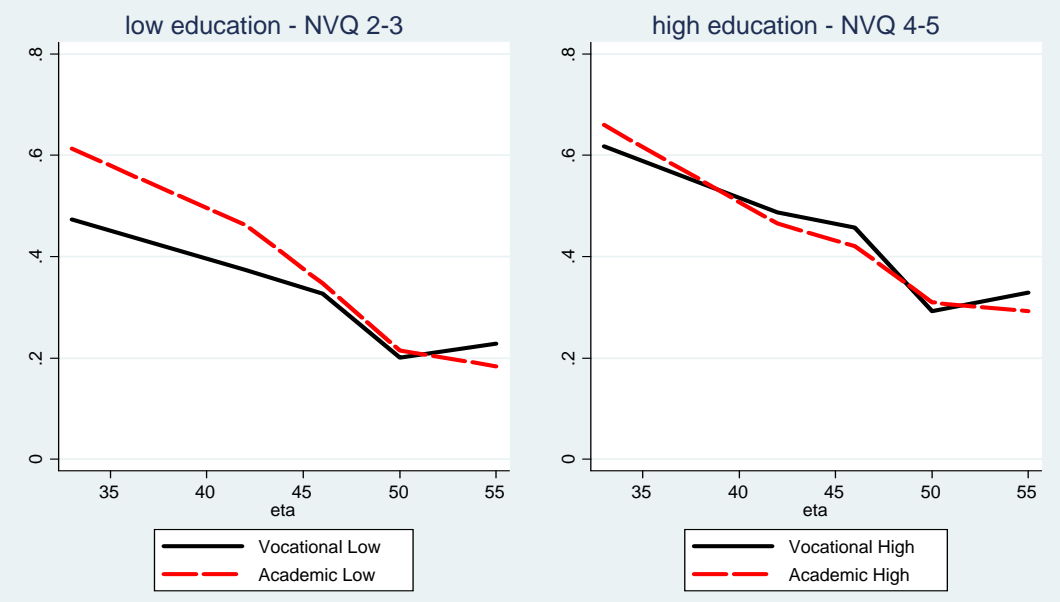
Figure 5. Simulated life cycle profile: employment. Lower education. Dominant and non dominant vocational versus academic education. Males. NCDS

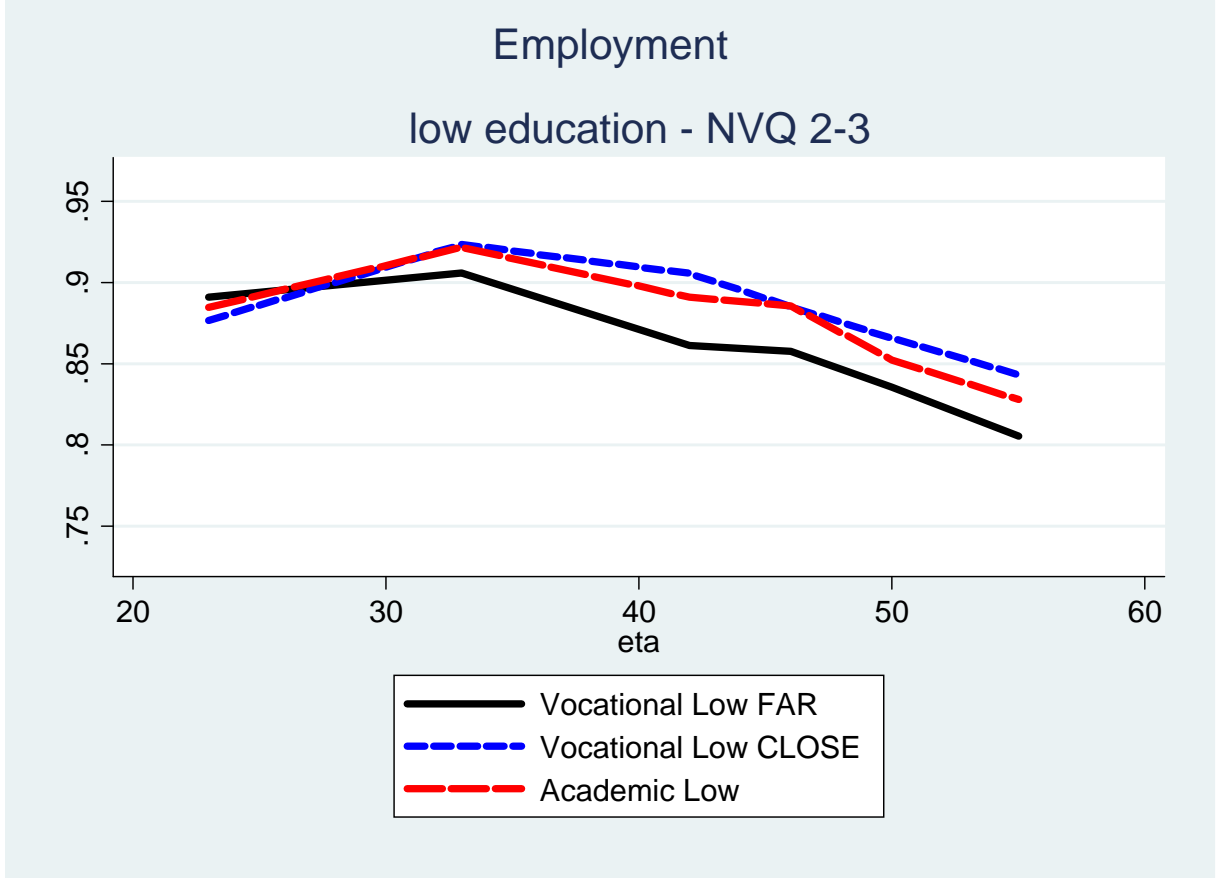

Figure 6. Simulated life cycle profile: net wages. Lower education. Dominant and non dominant vocational versus academic education. Males. NCDS

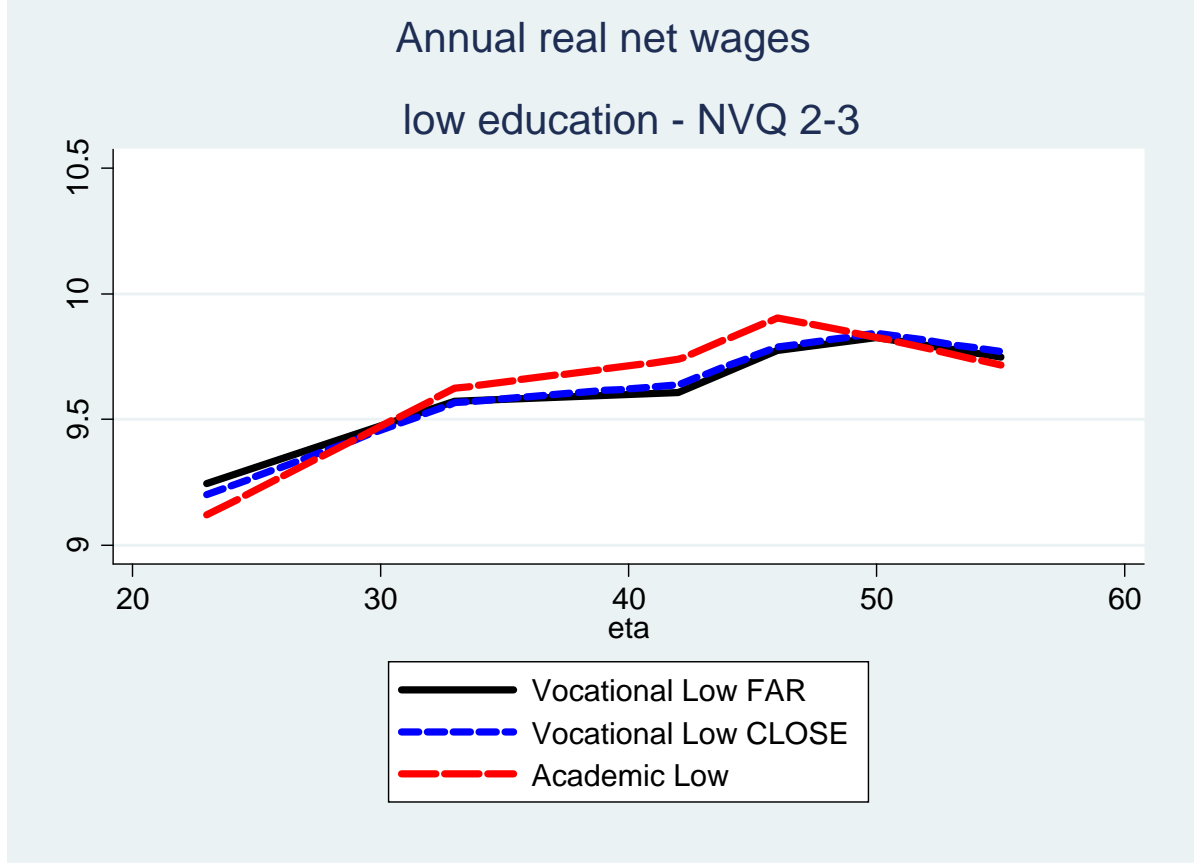


Figure 7. Simulated life cycle profile: employment. Males. BCS.

Employment
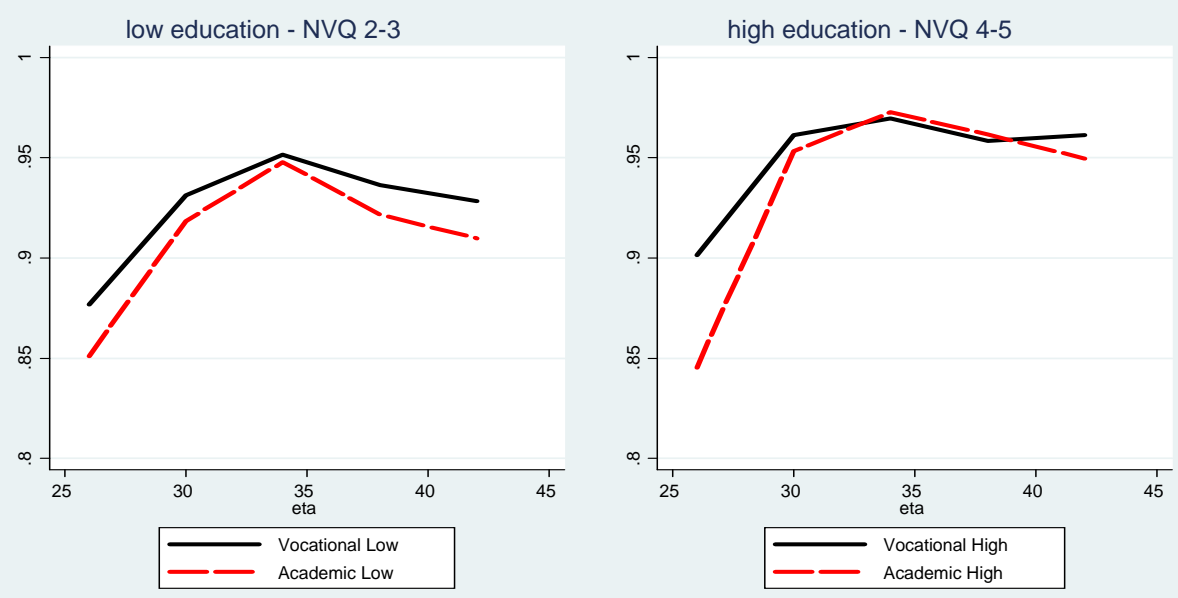

Figure 8. Simulated life cycle profile: real net wages. Males. BCS.

Annual real net wages
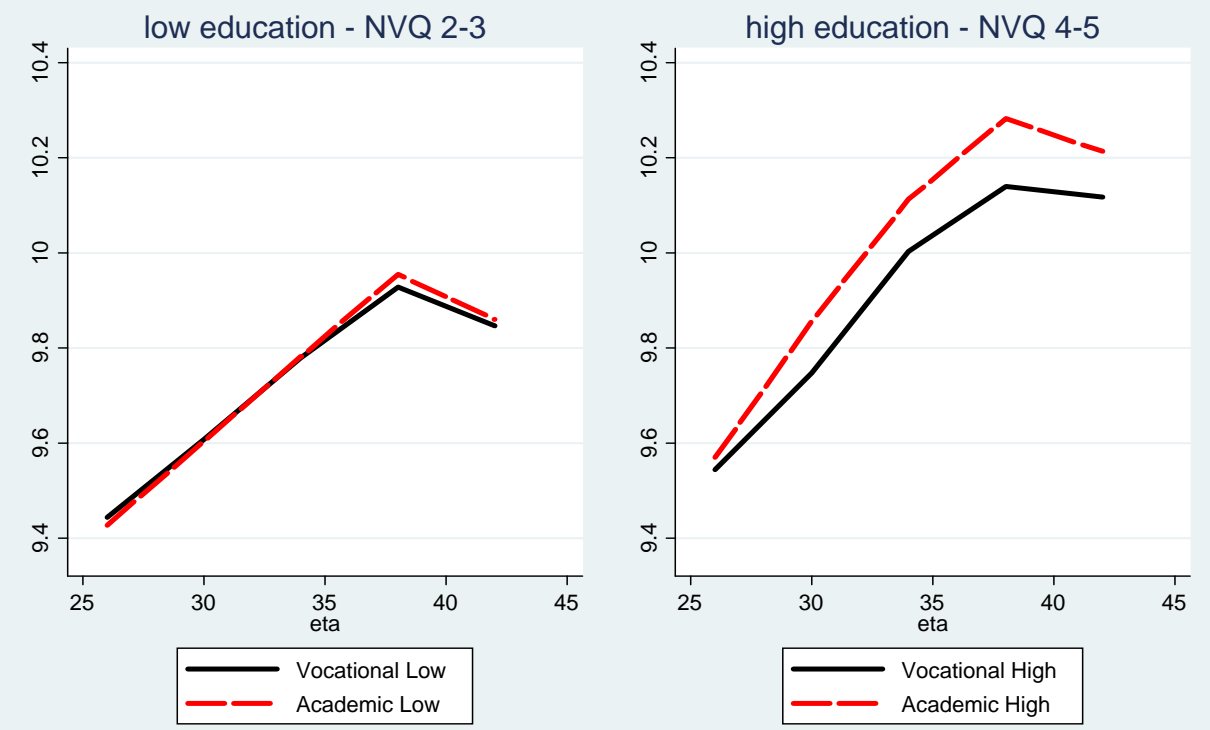
Figure 9. Simulated life cycle profile: employment. Lower education. Dominant and non dominant vocational versus academic education. Males. BCS

\section{Employment}

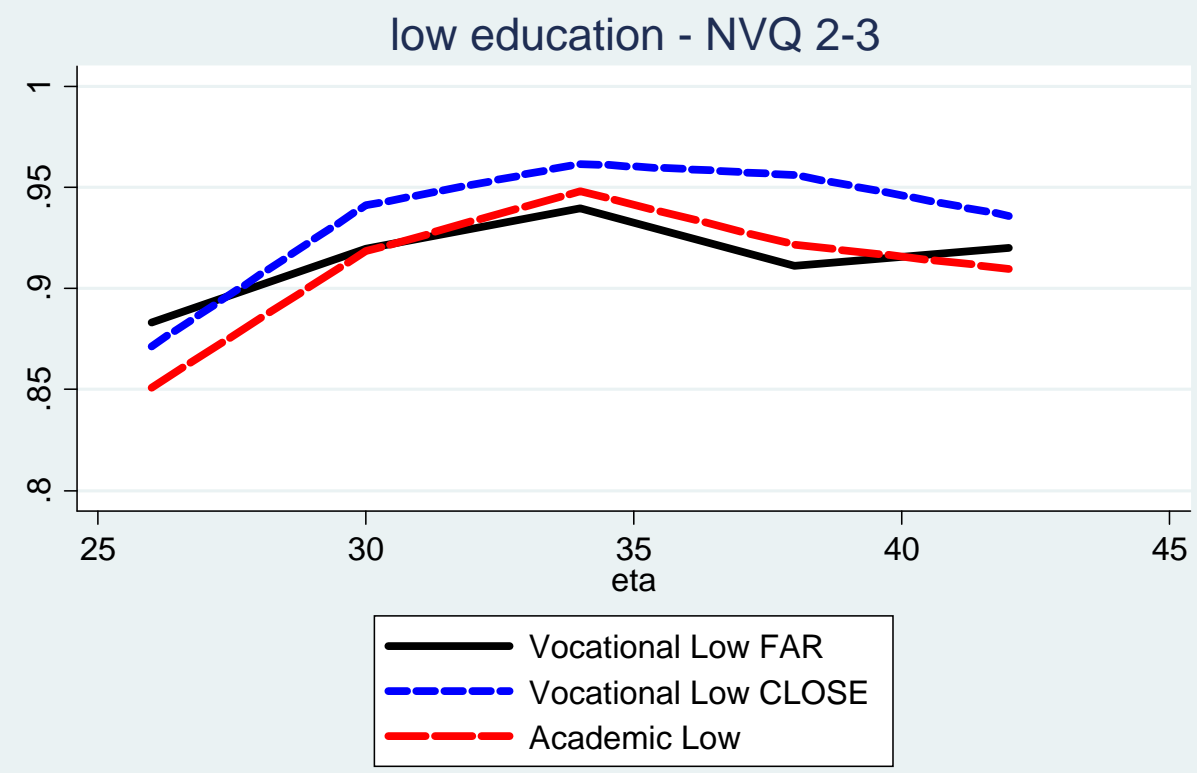

Figure 10. Simulated life cycle profile: real net wages. Lower education. Dominant and non dominant vocational versus academic education. Males. BCS

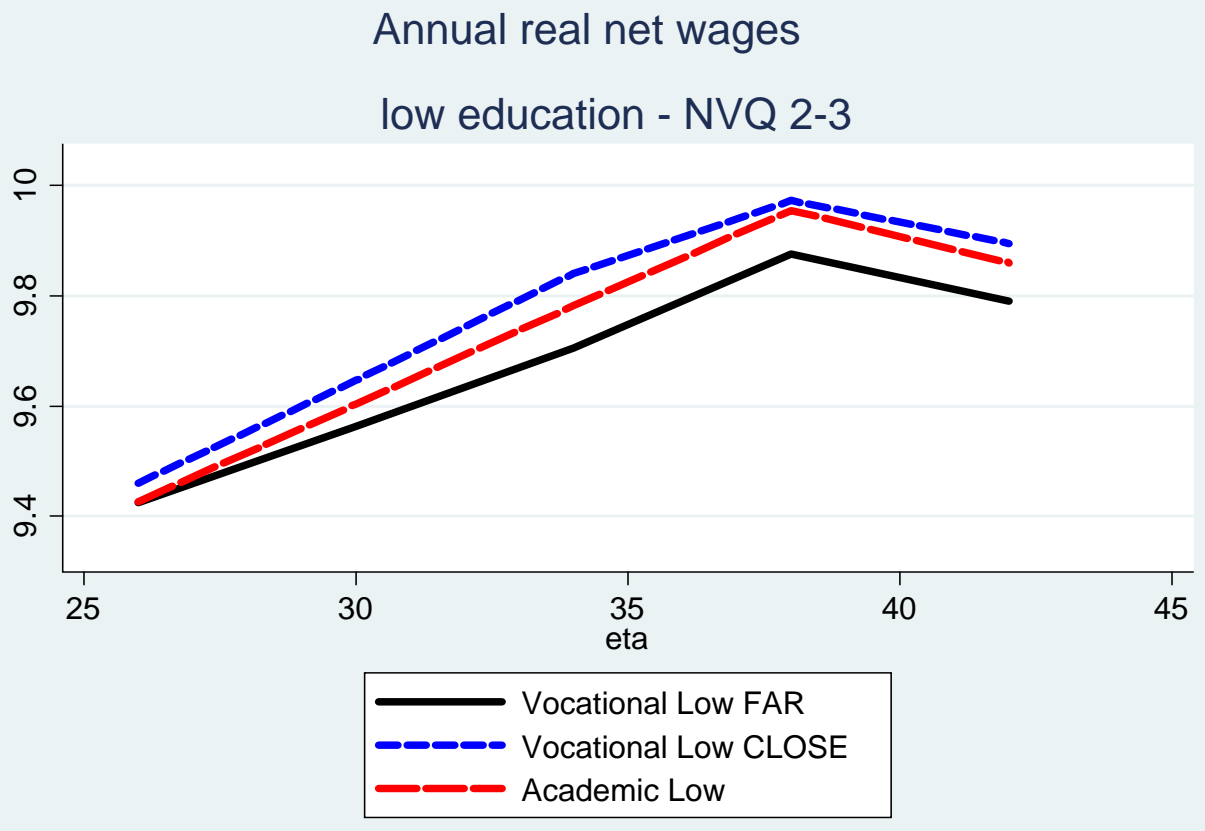




\section{Appendix}

\section{The AIPW Method.}

The AIPW is a GMM estimator that combines a treatment and an outcome model. In our setup, multiple treatments correspond to individual education choices, which include low education, lower academic and vocational education and higher academic and vocational education. Let the vector $\mathrm{T}$ be defined as $\mathrm{T} \epsilon\{\mathrm{LE}, \mathrm{G} 1, \mathrm{~V} 1, \mathrm{G} 2, \mathrm{~V} 2\}$. To provide an idea of how AIPW works, it is useful to discuss it as if it proceeded in steps. In the first step a multinomial logit model is estimated

$$
\operatorname{Pr}(\mathrm{T} \mid \mathrm{X})=\Lambda\left(\sigma_{0}+\sigma_{1} \mathrm{X}\right)
$$

where $\Lambda$ (.) is the 5 -variated logistic distribution. The estimated propensity scores associated to each treatment are denoted $p\left(T, X_{j}\right)$.

In the second step, -and separately by treatment, the observed outcome $Y$ at age 23 for individual $i$ is "regressed" on the vector $X$ and the regional unemployment rate $U$ and the potential outcomes (PO) corresponding to any possible treatment are predicted. Thus, all individuals, regardless the treatment they are actually assigned, are imputed five potential outcomes. Following Rubin and Laan, 2008, potential outcomes are obtained as follows. Define $\tau_{i}$ as the treatment actually assigned to individual $I$ and $\sigma_{i}$ as any possible (counterfactual) treatment and let $\mu\left(\mathrm{X}_{\mathrm{i}}, \mathrm{U}_{\mathrm{rt}}\right)$ be the predicted value of outcome $\mathrm{Y}$ derived from the outcome equation. The potential outcome PO for individual $i$, when assigned treatment $\sigma_{i}$, is:

$$
P O\left(\sigma_{i}, X_{i}, U_{r t}\right)=\mu\left(X_{i}, U_{r t}\right) \quad \text { if } \quad \sigma_{i} \neq \tau_{i}
$$

and

$$
P O\left(\sigma_{i}, X_{i}, U_{r t}\right)=\frac{1}{p\left(\sigma_{i}, X_{i}\right)} Y_{i t}+\left(1-\frac{1}{p\left(\sigma_{i}, X_{i}\right)}\right) \mu\left(X_{i}, U_{r t}\right) \text { if } \sigma_{i}=\tau_{i}
$$

The latter expression is a linear combination of the observed outcome $Y$ and the outcome predicted for an individual with the same observable characteristics, weighted by the propensity score (see Rubin and Laan 2008 for details). ${ }^{25}$

Finally, the average potential outcome associated to treatment $\sigma$ is given by

25 This estimator corresponds to the STATA 13 command "teffects aipw". 
$\overline{\mathrm{PO}}(\sigma)=\mathrm{E}\left(\mathrm{PO}\left(\sigma_{\mathrm{i}}, \mathrm{X}_{\mathrm{i}}, \mathrm{U}_{\mathrm{rt}}\right) \mid \sigma_{\mathrm{i}}=\sigma\right)$

\section{Macroeconomic variables.}

- Regional unemployment rate: we use the regional data from 1992 to 2012 kindly provided by Maria Paniagua using LFS data. 2013 data are from Eurostat. We estimate 1991 and 1981 data using the aggregate long - run unemployment statistics produced by the UK Govrnment Statistical Service, by assuming that regional and national dynamics are the same between 1981 and 1992;

- Consumer price index: ONS online statistics (2005=1).

\section{Definition of Vocational and Academic Education}

Table A1. Classification of educational qualifications - NCDS 1981 and BCS 1999

\begin{tabular}{|c|c|c|}
\hline Education level & Qualifications & NVQ \\
\hline Low education & $\begin{array}{l}\text { Any CSEs below grade 1, Less than } 5 \text { CSEs at grade 1, } \\
\text { Any GCSEs below grade C, Less than } 5 \text { GCSEs above } \\
\text { grade C, SCE ordinary grades D-E, standard grades 4- } \\
5 \text {, O levels D-E, Other Scottish School Qualifications, } \\
\text { Less than } 5 \text { O levels at A-C, 1AS level, GCSEs/O } \\
\text { levels/CSEs but don't know how many, Other BTEC, } \\
\text { Other CG, Other RSA, Other Pitmans, Trusts towards } \\
\text { NVQ, Other NVQ, HGV, Other Vocational, Don't } \\
\text { know BTEC, RSA; CG, Pitmans, NVQ level, } \\
\text { Foundation level, BTEC First/Academic certificate, } \\
\text { CG part 1, RSA Certificate, Pitmans level 1, NVQ level } \\
1\end{array}$ & 0,1 \\
\hline Academic level 1 (G1) & $\begin{array}{l}5 \text { or more GCSEs at A-C, } 5 \text { or more O levels at A-C, } 5 \\
\text { or more CSEs at Grade } 1 \text {, Sum of Good GCSEs, Os } \\
\text { and CSEs } 5 \text { or more, } 2 \text { or } 3 \text { AS levels, } 1 \text { A level, any } \\
\text { SCE standard grade } 1-3 \text {, or ordinary A-C, SUPE low or } \\
\text { ordinary, } 4 \text { or more AS levels, more than } 1 \text { A level, } \\
\text { Scottish Highers, Scottish Certificate of } 6^{\text {th }} \text { Year } \\
\text { Studies, Access Course }\end{array}$ & 2,3 \\
\hline Academic level 2 (G2) & Degree, Higher Degree, Diploma of Higher Education & 4,5 \\
\hline Vocational level 1 (V1) & Intermediate Level, BTEC First/Academic Diploma, & $2-3$ \\
\hline
\end{tabular}




\begin{tabular}{l|l|c|}
\hline & $\begin{array}{l}\text { BTEC National Certificate, ONC/OND, CG Part } \\
\text { 2/Craft/Intermediate, CG Part 3/Final/Advanced } \\
\text { Craft, RSA First or Advanced Diploma, Pitmans Level } \\
\text { 2/3, NVQ 2/3, Apprenticeship }\end{array}$ & \\
\hline Vocational level 2 (V2) & $\begin{array}{l}\text { BTEC Higher Certificate, HNC/HND, CG Part 4, } \\
\text { RSA Higher Diploma, NVQ 4/5, Other teaching } \\
\text { Qualification, PGCE, Nursing, Another Degree level } \\
\text { Qualification }\end{array}$ & 4,5 \\
\hline
\end{tabular}

Sources: Dearden et al, 2004.

Table A2. Summary statistics of early life conditions. NCDS 1981.

\begin{tabular}{lcc}
\hline & Mean & Std Dvt \\
\hline Mother smoked during pregnancy & 0.37 & 0.48 \\
Mother shows interest in the child's education & 0.33 & 0.47 \\
Was breastfed & 0.60 & 0.49 \\
Mother not in school after 16 & 0.70 & 0.45 \\
Father in low ranking occupation & 0.25 & 0.43 \\
Mother reads to child & 0.44 & 0.49 \\
Left-handed & 0.10 & 0.30 \\
No abnormal patterns in delivery & 0.70 & 0.45 \\
Father not in school after 16 & 0.79 & 0.41 \\
Weight at birth in ounces & 110 & 37.6 \\
Reading test score at 7 & 0.69 & 0.32 \\
Math test score at 11 & 15.66 & 11.54 \\
Reading test score at 11 & 14.41 & 8.21 \\
Height at 7 & 1.017 & 0.46 \\
\hline
\end{tabular}


Table A3. Fixed effects estimates. Males. NCDS.

\begin{tabular}{|c|c|c|c|c|}
\hline & Employment & Net wage & $\begin{array}{c}\text { Any new } \\
\text { qualification } \\
\text { since last } \\
\text { interview }\end{array}$ & $\begin{array}{l}\text { Any training } \\
\text { since last } \\
\text { interview }\end{array}$ \\
\hline Age $=33$ & $\begin{array}{l}-0.03 \\
(0.02)\end{array}$ & $\begin{array}{c}0.37 * * * \\
(0.03)\end{array}$ & - & - \\
\hline A ge $=42$ & $\begin{array}{l}-0.05 \\
(0.03)\end{array}$ & $\begin{array}{c}0.42^{* * *} \\
(0.05)\end{array}$ & $\begin{array}{c}-0.16 * * * \\
(0.03)\end{array}$ & $\begin{array}{c}-0.10 * * * \\
(0.03)\end{array}$ \\
\hline Age $=46$ & $\begin{array}{c}-0.06^{* *} \\
(0.03)\end{array}$ & $\begin{array}{c}0.60^{* * *} \\
(0.06)\end{array}$ & $\begin{array}{c}-0.08^{* *} \\
(0.03)\end{array}$ & $\begin{array}{c}-0.11 * * * \\
(0.04)\end{array}$ \\
\hline Age $=50$ & $\begin{array}{c}-0.08 * * * \\
(0.03)\end{array}$ & $\begin{array}{c}0.63^{* * *} \\
(0.05)\end{array}$ & $\begin{array}{c}-0.07 * * \\
(0.03)\end{array}$ & $\begin{array}{c}-0.24 * * * \\
(0.03)\end{array}$ \\
\hline Age $=55$ & $\begin{array}{c}-0.11 * * * \\
(0.03)\end{array}$ & $\begin{array}{c}0.55^{* * *} \\
(0.05)\end{array}$ & $\begin{array}{c}-0.14 * * * \\
(0.03)\end{array}$ & $\begin{array}{c}-0.22 * * * \\
(0.03)\end{array}$ \\
\hline Age $=33 * \mathrm{~V} 1$ & $\begin{array}{c}0.06^{* * *} \\
(0.02)\end{array}$ & $\begin{array}{l}-0.03 \\
(0.02)\end{array}$ & - & - \\
\hline Age $=33 * \mathrm{G} 1$ & $\begin{array}{c}0.06^{* * *} \\
(0.02)\end{array}$ & $\begin{array}{c}0.14^{* * *} \\
(0.03)\end{array}$ & - & - \\
\hline Age $=33 * \mathrm{~V} 2$ & $\begin{array}{c}0.03 \\
(0.03)\end{array}$ & $\begin{array}{c}0.19 * * * \\
(0.03)\end{array}$ & - & - \\
\hline Age $=33 * G 2$ & $\begin{array}{c}0.20 * * * \\
(0.02)\end{array}$ & $\begin{array}{c}0.34 * * * \\
(0.03)\end{array}$ & - & - \\
\hline Age $=42 * V 1$ & $\begin{array}{c}0.04 * * \\
(0.02)\end{array}$ & $\begin{array}{l}-0.03 \\
(0.04)\end{array}$ & $\begin{array}{l}-0.05 \\
(0.03)\end{array}$ & $\begin{array}{l}-0.00 \\
(0.03)\end{array}$ \\
\hline Age $=42 * \mathrm{G} 1$ & $\begin{array}{c}0.05^{* *} \\
(0.02)\end{array}$ & $\begin{array}{c}0.20 * * * \\
(0.04)\end{array}$ & $\begin{array}{l}-0.05 \\
(0.03)\end{array}$ & $\begin{array}{l}-0.05 \\
(0.04)\end{array}$ \\
\hline Age $=42 * V 2$ & $\begin{array}{c}0.01 \\
(0.03)\end{array}$ & $\begin{array}{c}0.24 * * * \\
(0.06)\end{array}$ & $\begin{array}{c}-0.11 * * \\
(0.05)\end{array}$ & $\begin{array}{l}-0.03 \\
(0.05)\end{array}$ \\
\hline Age $=42 * G 2$ & $\begin{array}{c}0.18^{* * *} \\
(0.03)\end{array}$ & $\begin{array}{c}0.32^{* * *} \\
(0.05)\end{array}$ & $\begin{array}{c}-0.16^{* * * *} \\
(0.04)\end{array}$ & $\begin{array}{c}-0.10 * * * \\
(0.04)\end{array}$ \\
\hline Age $=46 * V 1$ & $\begin{array}{c}0.04 * * \\
(0.02)\end{array}$ & $\begin{array}{c}-0.05^{*} \\
(0.03)\end{array}$ & $\begin{array}{c}-0.08 * * * \\
(0.03)\end{array}$ & $\begin{array}{l}-0.03 \\
(0.04)\end{array}$ \\
\hline Age $=46 * \mathrm{G} 1$ & $\begin{array}{c}0.06^{* * *} \\
(0.02)\end{array}$ & $\begin{array}{c}0.18^{* * *} \\
(0.04)\end{array}$ & $\begin{array}{c}-0.12 * * * \\
(0.04)\end{array}$ & $\begin{array}{c}-0.15 * * * \\
(0.04)\end{array}$ \\
\hline $\mathrm{Age}=46 * \mathrm{~V} 2$ & $\begin{array}{c}0.02 \\
(0.03)\end{array}$ & $\begin{array}{c}0.30^{* * *} \\
(0.04)\end{array}$ & $\begin{array}{c}-0.16^{* * *} \\
(0.05)\end{array}$ & $\begin{array}{l}-0.05 \\
(0.06)\end{array}$ \\
\hline Age $=46 * G 2$ & $\begin{array}{c}0.18^{* * *} \\
(0.03)\end{array}$ & $\begin{array}{c}0.41 * * * \\
(0.04)\end{array}$ & $\begin{array}{c}-0.28^{* * * *} \\
(0.04)\end{array}$ & $\begin{array}{c}-0.13^{* * * *} \\
(0.04)\end{array}$ \\
\hline Age $=50 * \mathrm{~V} 1$ & $\begin{array}{l}0.04^{*} \\
(0.02)\end{array}$ & $\begin{array}{l}-0.03 \\
(0.03)\end{array}$ & $\begin{array}{c}-0.09 * * * \\
(0.03)\end{array}$ & $\begin{array}{l}-0.03 \\
(0.04)\end{array}$ \\
\hline Age $=50 * \mathrm{G} 1$ & $\begin{array}{l}0.04 * \\
(0.02)\end{array}$ & $\begin{array}{c}0.07 \\
(0.04)\end{array}$ & $\begin{array}{c}-0.09 * * \\
(0.04)\end{array}$ & $\begin{array}{c}-0.16^{* * * *} \\
(0.04)\end{array}$ \\
\hline Age $=50 * \mathrm{~V} 2$ & $\begin{array}{c}0.04 \\
(0.03)\end{array}$ & $\begin{array}{c}0.28^{* * *} \\
(0.05)\end{array}$ & $\begin{array}{c}-0.23 * * * \\
(0.05)\end{array}$ & $\begin{array}{l}-0.09 \\
(0.06)\end{array}$ \\
\hline Age $=50 * \mathrm{G} 2$ & $\begin{array}{c}0.19^{* * *} \\
(0.03)\end{array}$ & $\begin{array}{c}0.36^{* * *} \\
(0.05)\end{array}$ & $\begin{array}{c}-0.29 * * * \\
(0.04)\end{array}$ & $\begin{array}{c}-0.11^{* *} \\
(0.04)\end{array}$ \\
\hline Age $=55 * \mathrm{~V} 1$ & $\begin{array}{c}0.05^{* *} \\
(0.02)\end{array}$ & $\begin{array}{l}-0.02 \\
(0.04)\end{array}$ & $\begin{array}{c}-0.08^{* *} \\
(0.03)\end{array}$ & $\begin{array}{l}-0.02 \\
(0.04)\end{array}$ \\
\hline Age $=55 * \mathrm{G} 1$ & $\begin{array}{l}0.05^{*} \\
(0.03)\end{array}$ & $\begin{array}{c}0.05 \\
(0.05)\end{array}$ & $\begin{array}{l}-0.05 \\
(0.04)\end{array}$ & $\begin{array}{c}-0.21 * * * \\
(0.05)\end{array}$ \\
\hline Age $=55 * \mathrm{~V} 2$ & $\begin{array}{l}-0.00 \\
(0.04)\end{array}$ & $\begin{array}{c}0.32^{* * *} \\
(0.05)\end{array}$ & $\begin{array}{c}-0.17 * * * \\
(0.05)\end{array}$ & $\begin{array}{l}-0.07 \\
(0.06)\end{array}$ \\
\hline Age $=55 * G 2$ & $\begin{array}{c}0.14 * * * \\
(0.03)\end{array}$ & $\begin{array}{c}0.40^{* * *} \\
(0.05)\end{array}$ & $\begin{array}{c}-0.23 * * * \\
(0.04)\end{array}$ & $\begin{array}{c}-0.15^{* * *} \\
(0.05)\end{array}$ \\
\hline Observations & 17,222 & 9,798 & 11,043 & 11,043 \\
\hline R-squared & 0.039 & 0.525 & 0.112 & 0.100 \\
\hline $\mathrm{P}$ - value test additional interactions & .167 & .001 & .010 & .245 \\
\hline
\end{tabular}

Note: each regression includes a constant, the regional unemployment rate and the interactions of age with a vector of early life conditions, including ability measures at 7 and 11 . Robust standard errors clustered at the individual level within parentheses. V1: low vocational education; G1: low academic education; V2: high vocational education; G2: high academic education. 


\section{References}

Acemoglu, D, 2000, Technical Change, Inequality and the Labour Market, NBER Working Paper 7800.

Altonji J., Blom E and Costas Meghir, 2012. Heterogeneity in Human Capital Investments: High School Curriculum, College Major, and Careers, Annual Review of Economics, Annual Reviews, Annual Reviews, vol. 4(1), pages 185-223, 07

Bibby D., Buscha F., Cerqua A., Thomson D. and Unwin P., (2014), Estimation of the labour market returns qualifications gained in English further education, Department for Business Innovation \& Skills, UK Government.

Bishop, John H., and Ferran Mane. 2004. The impacts of career-technical education on high school labour market success. Economics of Education Review 23(4): 381-402.

Blanden J. and Stephen Machin, 2004. Educational Inequality and the Expansion of UK Higher Education, Scottish Journal of Political Economy, Scottish Economic Society, vol. 51(2), pages 230-249, 05.

Blundell, R, Dearden L, Goodman A and Howard Reed, 2000. The Returns to Higher Education in Britain: Evidence from a British Cohort, Economic Journal, Royal Economic Society, vol. 110(461), pages F82-99, February

Blundell R, Dearden L and Barbara Sianesi, 2005. Evaluating the effect of education on earnings: models, methods and results from the National Child Development Survey, Journal of the Royal Statistical Society Series $A$, Royal Statistical Society, vol. 168(3), pages 473-512.

Blundell R \& Monica Costa Dias, 2009. "Alternative Approaches to Evaluation in Empirical Microeconomics," Journal of Human Resources, University of Wisconsin Press, vol. 44(3).

Brunello, G, Weber, G \& Weiss, CT., 2015. Books Are Forever: Early Life Conditions, Education and Lifetime Income, The Economic Journal, forthcoming.

Brunello, G and Rocco Lorenzo, 2015, The Effects of Vocational Education on Adult Skills and Wages. What can we learn from PIAAC? OECD Social, Employment and Migration Working Papers, 168.

Cattaneo, MD., (2010). Efficient semiparametric estimation of multi-valued treatment effects under ignorability, Journal of Econometrics, Elsevier, vol. 155(2), pages 138-154.

Card, D and Thomas Lemieux, 2001. "Can Falling Supply Explain The Rising Return To College For Younger Men? A Cohort-Based Analysis," The Quarterly Journal of Economics, MIT Press, vol. 116(2), pages 705-746, May.

CEDEFOP, 2008, Initial vocational education and training in Europe, Thessaloniki.

CEDEFOP, 2013, Labour Market Outcomes of Vocational Education in Europe, Research Paper n. 32, Thessaloniki.

Dearden, L, 1999. "The effects of families and ability on men's education and earnings in Britain," Labour Economics, Elsevier, vol. 6(4), pages 551-567, November.

Dearden, Lorraine, Steven McIntosh, Michal Myck, and Anna Vignoles. 2002. "The Returns to Academic and Vocational Qualifications in Britain." Bulletin of Economic Research 54(3): 249-74.

Dearden, L, McGranahan L and Barbara Sianesi. 2004. An In-Depth Analysis of the Returns to National Vocational Qualifications Obtained at level 2. CEE Discussion Papers 0046. Centre for the Economics of Education.

Devereux, Paul J. \& Fan, Wen, 2011. Earnings returns to the British education expansion, Economics of Education Review, Elsevier, vol. 30(6), pages 1153-1166

Dodgeon, B., Hancock, M., Johnson, J. and Parsons, S., 2011, Deriving Highest Qualification in NCDS and BCS70, CLS Data Note, 2011/1

Dolton, P. J. \& Vignoles, A., 2002. "Is a broader curriculum better?," Economics of Education Review, Elsevier, vol. 21(5), pages 415-429, October. 
Eichhorst, Werner \& Rodríguez-Planas, Núria \& Schmidl, Ricarda \& Zimmermann, Klaus. 2012. A Roadmap to Vocational Education and Training Systems around the World, IZA Discussion Papers 7110.

Elsby, Michael and Jennifer Smith, 2010, The Great Recession in the UK Labour Market: a Transatlantic Perspective, National Institute Economic Review.

Fersterer, J. and Winter Ebmer R., 2008. Returns to apprenticeship training in Austria: evidence from failed firms. Scandinavian Journal of Economics, Vol. 110, No 4, pp. 733-753.

Galindo-Rueda, F and Anna Vignoles, 2007, The heterogeneous Effects of Selection in UK Secondary Schools, in Woessmann, L. and Peterson P, eds., Schools and the Equal Opportunity Problem, MIT Press.

Golsteyn, B and A. Stenberg, 2015, Comparing long term earnings trajectories of individuals with general and specific education, paper presented at the EALE 2014 Conference.

Green, A., 2002, The many faces of lifelong learning: recent education policy trends in Europe, Journal of Education Policy, 611-626

Green, A, Wolf, A and Laney, T, 1999, Convergence and divergence in European education and training systems, Institute of Education, London

Hall, Caroline. 2012. The Effects of Reducing Tracking in Upper Secondary School: Evidence from a Large-Scale Pilot Scheme. Journal of Human Resources 47(1): 237-69.

Hanushek, Eric A., Ludger Woessmann, and Lei Zhang. 2011. "General Education, Vocational Education and Labor Market Outcomes over the Life-Cycle.” IZA Discussion Paper 6083.

Hotchkiss, Lawrence. 1993. Effects of Training, Occupation, and Training-Occupation Match on Wage. Journal of Human Resources 28(3): 482-496.

Lindeboom, Maarten \& Lundborg, Petter \& van der Klaauw, Bas, 2009. Obesity and Labor Market Outcomes: Evidence from the British NCDS, IZA Discussion Papers 4099, Institute for the Study of Labor (IZA)

Krueger, Dirk, and Krishna B. Kumar. 2004. Skill-specific rather than general education: A reason for USEurope Growth Differences? Journal of Economic Growth 9:167-207.

Makepeace G and Dolton P, 2001, What can the National Child Development Study and the 1970 British Cohort Study tell us about the individual's acquisition and use of education and training? CLS Working Paper.

Malamud, O.; Pop-Eleches, C. 2010. General education versus vocational training: evidence from an economy in transition. Review of Economics and Statistics, February 2010, Vol. 92, No 1, pp. 43-60.

Meer, Jonathan. 2007. Evidence on the Returns to Secondary Vocational Education. Economics of Education Review 26(5): 559-73.

Oosterbeek, Hessel, and Dinand Webbink. 2007. Wage Effects of an Extra Year of Basic Vocational Education. Economics of Education Review 26(4): 408-19.

Pischke, Jorn Steffen, and Till von Wachter. 2008. Zero Returns to Compulsory Schooling in Germany: Evidence and Interpretation. The Review of Economics and Statistics 90(3): 592-98.

Quintini, Glenda, and Thomas Manfredi. 2009. Going Separate Ways? School-to-Work Transitions in the United States and Europe. OECD Social, Employment and Migration Working Paper 90.

Ryan, P. 2001. The school-to-work transition: a cross-national perspective. Journal of economic literature, March 2001, Vol. 39, No 1, pp. 34-92.

Ryan, P. 2003, Evaluating Vocationalism, European Journal of Education, Vol. 38, No. 2, 2003

Robinson, Peter. 1997. The Myth of Parity of Esteem: Earnings and Qualifications. Discussion Paper 354, London School of Economics: Centre for Economic Performance.

Schneider, S, 2008, The application of the ISCED-97 to the UK's educational qualifications, MZES.

Verhaest, D and Baert, S, 2015, The Early Labour Market Effects of Generally and Vocationally Oriented Higher Education: Is There a Trade-off?, IZA DP 9137 
Walker, Ian \& Zhu, Yu, 2011. "Differences by degree: Evidence of the net financial rates of return to undergraduate study for England and Wales," Economics of Education Review, Elsevier, vol. 30(6), pages 1177-1186.

Wolf, Alison, 2011, Review of Vocational Education: the Wolf Report, mimeo

Wooldridge, Jeffrey M., 2010. Econometric Analysis of Cross Section and Panel Data. 2nd edition. MIT Press

Wolter, Stefan C., and Paul Ryan. 2011. Apprenticeship. In Eric Hanushek, Stephen Machin and Ludger Woessmann, ed., Handbook of Economics of Education 3(3), Elsevier 